\title{
THE
}

\section{Synthesis and Evaluation of Tripodal Peptide Analogues for Cellular Delivery of Phosphopeptides}

\author{
Guofeng Ye \\ University of Rhode Island \\ Nguyen-Hai Nam \\ University of Rhode Island \\ Anil Kumar \\ University of Rhode Island \\ Ali Saleh \\ University of Rhode Island \\ Dinesh B. Shenoy
}

See next page for additional authors

Follow this and additional works at: https://digitalcommons.uri.edu/bps_facpubs

This is a pre-publication author manuscript of the final, published article.

Terms of Use

All rights reserved under copyright.

\section{Citation/Publisher Attribution}

Ye, G., Nam, N.-H., Kumar, N., Saleh, A., Shenoy, D. B., Amiji, M. M., Lin, X.,...Parang, K. (2007). Synthesis and Evaluation of Tripodal Peptide Analogues for Cellular Delivery of Phosphopeptides. J. Med. Chem., 50(15), 3604-3617. doi: 10.1021/jm070416o

Available at: https://doi.org/10.1021/jm070416o

This Article is brought to you for free and open access by the Biomedical and Pharmaceutical Sciences at DigitalCommons@URI. It has been accepted for inclusion in Biomedical and Pharmaceutical Sciences Faculty Publications by an authorized administrator of DigitalCommons@URI. For more information, please contact digitalcommons-group@uri.edu. 


\section{Authors}

Guofeng Ye, Nguyen-Hai Nam, Anil Kumar, Ali Saleh, Dinesh B. Shenoy, Mansoor M. Amiji, Xiaofeng Lin, Gongqin Sun, and Keykavous Parang 


\title{
Synthesis and Evaluation of Tripodal Peptide Analogues for Cellular Delivery of Phosphopeptides
}

\author{
Guofeng Yea, Nguyen-Hai Nam ${ }^{\mathrm{a}}$, Anil Kumara, Ali Saleh ${ }^{\mathrm{a}}$, Dinesh B. Shenoyc, Mansoor M. \\ Amijic, Xiaofeng Lin ${ }^{\mathrm{b}}$, Gongqin Sun ${ }^{\mathrm{b}}$, and Keykavous Parang ${ }^{\mathrm{a}^{*}}$ \\ aDepartment of Biomedical and Pharmaceutical Sciences, University of Rhode Island, Kingston, RI 02881 \\ USA \\ bDepartment of Cell and Molecular Biology, University of Rhode Island, Kingston, RI 02881 USA \\ cDepartment of Pharmaceutical Sciences, Northeastern University, Boston, MA 02115 USA.
}

\section{Abstract}

Tripodal peptide analogues were designed based on the phosphotyrosine binding pocket of the Src SH2 domain and assayed for their ability to bind to fluorescein-labeled phosphopeptides. Fluorescence polarization assays showed that a number of amphipathic linear peptide analogues (LPAs), such as LPA4, bind to fluorescein-labeled GpYEEI (F-GpYEEI). LPA4 was evaluated for potential application in cellular delivery of phosphopeptides. Fluorescence microimaging cellular uptake studies with fluorescein-attached LPA4 (F-LPA4) alone or the mixture of LPA4 and FGpYEEI in BT-20 cells showed dramatic increase of the fluorescence intensity in cytosol of cells, indicating that LPA4 can function as a delivery tool of F-GpYEEI across the cell membrane. Fluorescent flow cytometry studies showed the cellular uptake of F-LPA4 in an energy-independent pathway, and confirmed the cellular uptake of F-GpYEEI in the presence of LPA4. These studies suggest that amphipathic tripodal peptide analogues, such as LPA4, can be used for cellular delivery of phosphopeptides.

\section{Keywords}

Phosphopeptides; molecular transporter; positively charged residues; peptide analogues; amphipathic property; fluorescence cytometry; fluorescence polarization

\section{Introduction}

Recently, several classes of cell-penetrating peptides have been introduced as potential transporters of other compounds that have low bioavailability across cell membranes. ${ }^{1-5}$ For example, arginine oligomers containing six or more amino acids, either alone or when conjugated to therapeutic agents have been shown to cross readily a variety of cell types very efficiently. ${ }^{6-22}$ In general, cell-penetrating peptides are polybasic (high guanidinium content), $20-24$ hydrophobic, ${ }^{25}$ or amphipathic. ${ }^{4,26}$ These properties determine the mechanism of the cellular uptake by these compounds.

Phosphopeptides have proven to be very valuable reagents for the study of protein phosphorylation and dephosphorylation. These compounds have been used to probe substrate

*Corresponding author: K. Parang: 41 Lower College Road, Department of Biomedical and Pharmaceutical Sciences, College of Pharmacy, University of Rhode Island, Kingston, Rhode Island, 02881, USA; Tel.: +1-401-874-4471; Fax: +1-401-874-5787; E-mail address: kparang@uri.edu. 
specificity of the Src homology 2 (SH2) domain, 27 phosphotyrosine binding (PTB) domains, 28,29 and phosphatases 30,31 in cell-free systems. Interactions between the negatively charged phosphate group of phosphopeptides or phosphoproteins and positively charged amino acids in binding pockets of a number of proteins have been demonstrated to be critical in several protein-ligand or protein-protein interactions. 32,33

Studies of phosphopeptides in cellular systems are complicated by the fact that in general phosphopeptides do not readily cross cellular membranes due to poor transport of the negatively charged phosphate moiety through cell membranes. Chemical methods have been used for delivery of phosphopeptides ${ }^{34-36}$ by conjugating phosphopeptides to other carrier peptides in a single sequence of fusion construct. ${ }^{37}$ The phosphopeptide is separated from the carrier in the cellular environment of the cytoplasm. In all these examples, the phosphopeptides were covalently attached to carrier peptides. This approach has the disadvantage of need for the synthesis of the fusion conjugates. The conjugation method is costly because of coupling inefficiency of reactions. Furthermore, the covalently bound fusion constructs must be cleaved by a specific chemical or enzymatic reaction to release phosphopeptides upon the cellular uptake.

Prompted by the potential broad value of using phosphopeptide in studying signaling pathways in cellular environment, we initiated a program aimed to deliver negatively charged phosphopeptides to cells by using tripodal positively charged peptides and without using a covalent attachment. The structural features of tripodal positively charged peptides as carrier molecules were designed based on the $\mathrm{Src} \mathrm{SH} 2$ domain phosphotyrosine (pTyr) binding pocket.

pTyr-Glu-Glu-Ile (pYEEI) peptide template has been shown to be the optimal binding sequence for the Src SH2 domain of the Src kinase. ${ }^{27,38}$ The crystal structure of pYEEI in complex with the $\mathrm{Src} \mathrm{SH} 2$ domain reveals that the pTyr residue is buried in the deep hydrophilic pTyrbinding pocket, ${ }^{27}$ and interacts with three positively charged amino acids, $\operatorname{Arg} 158, \operatorname{Arg} 178$, and Lys206 located in a triangle positions relative to pTyr, through a network of hydrogen bonding and electrostatic interactions.

Based on this mode of interaction with three positively charged amino acids surrounding pTyr residue of pYEEI within the Src SH2 domain binding pocket, a number of tripodal peptides analogues were synthesized to elucidate whether they can have potential interactions with phosphopeptides and/or can be used for their cellular delivery. The peptides were designed to have at least three amino acids, including two Arg and one Lys residues, linked together through a linker. The positively charged side chains of the amino acids possibly form a triangle structure or create appropriate positioning for interactions with the negatively charged phosphopeptides.

These compounds included one cyclic peptide (CP), one dendrimer peptide analogue (DPA), and nine linear peptide analogues (LPA1-LPA9) containing short and long linkers (Figure 1). Short and long linkers in LPA analogues were used to determine the importance of spacing between three positively charges side chains of amino acids for providing appropriate interactions with the phosphopeptides. Fluorescent polarization assay was used to determine the binding and/or aggregation of these analogues with phosphopeptides. The potential of selected peptides for cellular delivery of phosphopeptides was investigated by using fluorescent microimgaing and flow cytometry. To the best of our knowledge, this is the first report of using a non-covalent approach for cellular delivery of phosphopeptides. 


\section{Results and Discussion}

\section{Chemistry}

All compounds were prepared by the solid-phase synthesis using standard $N$-(9-fluorenyl) methoxycarbonyl (Fmoc)-based chemistry. Crude peptides were precipitated by addition of cold diethyl ether $\left(\mathrm{Et}_{2} \mathrm{O}\right)$ and were purified by preparative reverse-phase HPLC. The chemical structures of oligomeric compounds were determined by a high-resolution PE Biosystems Mariner API time of flight electrospray mass spectrometer.

The cyclic peptide (CP) was synthesized (Scheme 1) by linking the three amino acid residues, Arg, Arg, and Lys with a $\beta$-alanine linker. Acetyl chloride was reacted with trityl alcohol resin $(\mathbf{1}, 0.61 \mathrm{mmol} / \mathrm{g})$ swelled in dry toluene at $60^{\circ} \mathrm{C}$ to afford trityl chloride resin (2). Resin 2 was subjected to reaction with $\mathbf{N}-\alpha-\mathrm{L}-\mathrm{Fmoc}-\mathrm{Glu}(\gamma-\mathrm{OAll})-\mathrm{OH}$ in dry DCM in the presence of $N, N$ diisopropylethylamine (DIPEA) to yield $\mathbf{3}$. Fmoc peptide chemistry on resin-bound amino acid 3 was carried out using 2-(1H-benzotriazole-1-yl)-1,1,3,3-tetramethyluronium hexafluorophosphate (HBTU) and $N$-methylmorpholine (NMM) as coupling and activating reagents, respectively, piperidine (20\% in DMF) as a deprotecting reagent, and $N, N$ dimethylformamide (DMF) as a solvent. The amino acids used in the sequence were Fmoc$\operatorname{Arg}(\mathrm{Pbf})-\mathrm{OH}, \mathrm{Fmoc}-\beta$-Ala-OH, Fmoc-Arg(Pbf)-OH, Fmoc- $\beta$-Ala-OH, and Fmoc-Lys(Boc)$\mathrm{OH}$, respectively, to yield $\mathbf{4}$. The allyl group was deprotected by treatment of $\mathbf{4}$ with $\mathrm{CHCl}_{3} /$ $\mathrm{AcOH} / \mathrm{NMM}(37: 2: 1)$ and $\mathrm{Pd}\left(\mathrm{Ph}_{3} \mathrm{P}\right)_{4}$ by mixing at room temperature for $3 \mathrm{~h}$. The $N$-Fmoc group was deprotected using piperidine in DMF for $10 \mathrm{~min}$. The cyclization was carried out by adding HBTU and DIPEA and mixing at room temperature for $16 \mathrm{~h}$. The peptide was cleaved from the resin using TFA/anisole/water (90:5:5) to afford CP.

The synthesis of DPA was started by branching from nitrogen containing Mmt group in ( $1 \mathrm{~N}$ Dde, $8 N$-Mmt-spermidine-4-yl)-carbonyl Wang resin (5) (Scheme 2). All the chains were then extended by using Fmoc peptide synthesis. For the deprotection of the Mmt group in $\mathbf{5}$ (0.43 $\mathrm{mmol} / \mathrm{g}$ ), the resin was suspended in a mixture of TFE/DCM (1:1). To the resulting suspension was added HOBt. The mixing was continued for $3 \mathrm{~h}$. The completely washed and dried resin in dry DMF was subjected to reaction with $N$ - $\alpha$-Fmoc-Lys(Dde)-OH in the presence of HBTU and DIPEA for $30 \mathrm{~min}$ at room temperature. The coupling reaction was repeated in another cycle for $1 \mathrm{~h}$ to afford $\mathbf{6}$.

Fmoc deprotection of 6 was performed in the presence of piperidine in DMF (20\%). The coupling reaction with the second amino acid, $\mathrm{FmocNH}\left(\mathrm{CH}_{2}\right)_{4} \mathrm{COOH}$, was carried out in the presence of HBTU and DIPEA to produce 7. Fmoc deprotection and subsequent coupling reaction with $N$ - $\alpha$-Fmoc-Lys $(t \mathrm{Bu})-\mathrm{OH}$ in $\mathbf{7}$ afforded $\mathbf{8}$.

The deprotection of Dde groups in $\mathbf{8}$ was carried out by reaction with hydrazine monohydrate in DMF (2\%) for 2 min. Coupling reaction with $N$ - $\alpha$-Fmoc- $\operatorname{Arg}(\mathrm{Pbf})-\mathrm{OH}$ using the condition described above for coupling afforded $\mathbf{9}$. Fmoc deprotection, followed by cleavage from the resin using TFA/DCM (50:50) produced DPA.

LPAs (Figure 1) were synthesized by the solid-phase Fmoc-based chemistry employing Fmoc$\operatorname{Arg}(\mathrm{pbf})$-Wang resin (10) or Fmoc-Lys(Boc)-Wang resin as starting amino acids and FmocL-amino acid as building blocks. The synthesis of LPA8 is shown as a representative example in Scheme 3 starting from Arg-attached Wang resin deptrotection, followed by coupling reaction with FmocNH $\left(\mathrm{CH}_{2}\right)_{11} \mathrm{COOH}$, FmocNH $\left(\mathrm{CH}_{2}\right)_{5} \mathrm{COOH}$, Fmoc-Lys(Boc)-OH, FmocNH $\left(\mathrm{CH}_{2}\right) \mathrm{COOH}$, FmocNH $\left(\mathrm{CH}_{2}\right)_{5} \mathrm{COOH}$, and Fmoc-Arg(Pbf)-OH, respectively. HBTU and NMM in DMF were used as coupling and activating reagents, respectively. Fmoc deprotection at each step was carried out using piperidine in DMF (20\%). A mixture of TFA/ 
anisole/water (90:5:5) was used for side chain deprotection of amino acids and cleavage of the synthesized peptide from the resin.

Phosphopeptides, such as GpYEEI, were labeled with 5(6)-carboxyfluorescein for fluorescent polarization assays. The fluorescent probes were synthesized according to the previously reported procedure. ${ }^{39,40}$ Fluorescein-labeled LPA4 (F-LPA4) was synthesized (Scheme 4) by coupling of 5-carboxyfluorescein succinimidyl ester with a Wang resin-bound peptide containing LPA-4 sequence and a glycine linker (12). Resin 12 and DIPEA were added to a solution of 5-carboxyfluorescein succinimidyl ester in anhydrous DMF. The mixture was shaken for $48 \mathrm{~h}$ at room temperature. The resin was cleaved using a solution of TFA/water/ triisopropylsilane ( $5.0 \mathrm{~mL}: 0.5 \mathrm{~mL}: 0.5 \mathrm{~mL}$ ) for $2.5 \mathrm{~h}$. The crude product was purified by preparative reverse-phase HPLC. The chemical structure of F-LPA4 was determined by a highresolution electrospray time of flight electrospray mass spectrometer.

\section{Binding of tripodal peptides to phosphopeptides}

Figure 2 illustrates the comparative binding of all peptide analogues to a fluorescein-labeled phosphopeptide probe, F-GpYEEI, using the fluorescence polarization (FP) assays according to the previously reported procedure. ${ }^{39,40}$ The FP intensity reflects the local mobility of the chromophore upon binding. The LPAs containing long linkers (LPA4-LPA9) showed dramatic increase of the FP values, suggesting that these compounds form high molecular weight complexes with less local mobility in the presence of F-GpYEEI. However, the LPAs containing short linkers (LPA1-LPA3), CP, and DPA showed very low fluorescence polarization values even at maximum peptide concentration $(500 \mu \mathrm{M})$ in the presence of the fluorescent probe.

The data in Figure 2 shows that the spacing between positively charged residues differentiates the binding of tripodal peptide analogues to phosphopeptides. Peptides containing longer linkers exhibited higher aggregation. The presence of the longer linkers appears to generate appropriate positioning of positively charged groups for interaction with phosphopeptides. Increased flexibility in the backbone could allow the positively charged head groups to interact more effectively with the negative charges of phosphopeptides. LPA4-LPA9 containing long chain hydrophobic linkers are more flexible than other compounds, and can form complexes with themselves and the phosphopeptide probes through a combination of hydrophobic and electrostatic interactions. On the other hand, CP, DPA, and LPA1-LPA3 have rigid structures or short linkers that will not allow the three positively charged amino acid side chains, either attached to the central backbone cyclic ring in CP or attached through short linkers in LPA1LPA3 and DPA, to create appropriate positioning of positively-charged groups for the interactions with the negatively charged F-GpYEEI. LPA4-LPA9 did not show any significant differences in generating maximum fluorescence polarization in the presence of F-GpYEEI, suggesting approximately similar local mobility and/or size of formed aggregates.

\section{The role of F-GpYEEl in the formation of complexes containing LPA4}

To determine whether the presence of F-GpYEEI contributes in the formation of the complexes with less local mobility or LPA4 can self-assemble to form such complexes in the absence of F-GpYEEI, a fluorescent derivative of LPA4, F-LPA4, was synthesized using 5carboxyfluorescein succinimidyl ester and LPA4 as described above. Figure 3 displays the results of incubation of different concentrations of LPA4 in the presence of F-GpYEEI ( 80 $\mathrm{nM})$ or F-LPA4 $(\mathrm{nM})$. These data showed the significant increase in the FP values of LPA4 + F-GpYEEI when compared to those of LPA4 + F-LPA4. Thus, the presence of negatively charged F-GpYEEI enhances the formation of high molecular weight complexes with less local mobility possibly through intermolecular electrostatic interactions with positively charged 
residues in LPA4. These data show that the complexes are not formed exclusively by selfassembly of LPA4.

\section{The binding of LPAs containing long linkers with other phosphopeptides}

To determine the structural requirements of phosphopeptides for the binding to the LPAs containing long linkers, a series of fluorescently labeled analogues of phosphopeptides were synthesized by using standard solid-phase chemistry as described above. LPA8 was assayed against other fluorescent peptide probes with different sequences (e.g., F-AMpYSSV, FpYTKM, and F-pYTSM). Figure 4 (left) displays the results of incubation of different concentrations of LPA8 with constant concentration of the fluorescent probes. The complex between LPA8 and F-GpYEEI exhibited higher fluorescence when compared with that of other fluorescein-labeled probes. The difference of the FP intensity of F-GpYEEI compared to the other three probes indicated that the interactions are sequence dependent and LPA8 prefer specific sequences for binding. The absence of glutamic acids in F-GpYTKM and F-GpYTSM reduced the aggregation between these peptides and LPA8 when compared with that of FGpYEEI. Figure 4 (right) displays the results of incubation of a number of fluorescent probes and control F-GpYEEI with LPA4. Replacement of the glutamic acids in F-GpYEEI with alanine residues in F-GpYAAI reduced the FP values. Furthermore, LPA4 did not interact significantly with F-LPA4 alone. Therefore, in addition to the phosphate group, the carboxylic acid side chains of glutamic acid in F-GpYEEI are contributing in the selectivity and aggregate formation, possibly through electrostatic interactions with positively charged groups in LPA4 or LPA8. We selected F-GpYEEI for further cellular uptake studies, because of its higher aggregation with LPA analogues and its importance in interaction with the Src SH2 domain. 27,38

\section{Cellular Uptake Studies}

The most common methods to study internalization of cell-penetrating peptides have been to visualize uptake by fluorescence microscopy and to measure it quantitatively by fluorescenceactivated cell sorter (FACS) analysis. Fluorescence microimaging and flow cytometry were used to determine the potential of the tripodal LPAs containing long hydrophobic linkers and arginine-lysine residues as molecular transporters or delivery tools of phosphopeptides into cells.

\section{Cellular uptake of F-LPA4}

Fluorescein-conjugated peptide, F-LPA4, was incubated with the BT-20 cells. A dramatic increase of the fluorescence intensity was observed in a time-dependent manner in cytosol of the cells, suggesting that the F-LPA4 can cross the cell membrane. Additionally, a cellular uptake assay was carried out using different concentrations of F-LPA4 $(5-100 \mu \mathrm{M})$, suggesting that the fluorescence intensity and therefore the cellular uptake of this compound were concentration-dependent (Figure 5).

\section{Cellular uptake of F-GpYEEI in the presence of LPA4}

Cellular uptake assay was carried out using MDA-MB-468 cells. Cellular uptake studies of FGpYEEI were carried out in the presence and absence of LPA4. Figure 6 shows when only the F-GpYEEI was incubated with the cells, the fluorescence intensity remains low even after 30 min incubation possibly because negatively charged F-GpYEEI cannot cross the cell membrane significantly. In the presence of LPA4 under similar conditions, a dramatic increase in the fluorescence intensity inside the cells was observed, suggesting that tripodal peptide LPA-4 can function as a delivery tool of F-GpYEEI across the cell membrane possibly by encapsulation of the probe. These data were consistent with the previous assay using BT-20 
cells, suggesting that LPA4 may be used as a transporter of negatively charged compounds like GpYEEI into cells.

Similarly, real time fluorescence microscopy after incubation of live BT-20 cells for $30 \mathrm{~min}$ with F-GpYEEI $(10 \mu \mathrm{M})$ and LPA4 $(50 \mu \mathrm{M})$ showed dramatic increase in the fluorescence intensity inside the cells (Figure 7). Similar experiments using the control (no compound), FGpYEEI alone, F-GpYEEI + LPA1 did not show any significant intracellular fluorescence.

\section{Cell viability assay}

BT-20 cell viability was assayed using Vi-Cell Cell Viability Analyzer (Beckman Coulter). The results are presented in Figure 8. Cells were viable $>96 \%$, suggesting that F-GpYEEI, FLPA4, F-GpYEEI + LPA1 and F-GpYEEI + LPA4 were not cytotoxic after incubation under experimental conditions used for the cellular assays. Cell viability assay indicated that cells were not killed in the presence of different analogues; therefore, the cell penetration was not due to cell death.

\section{Flow cytometry studies}

The ability of these fluorescently labeled peptides to enter cells was then analyzed and the intracellular fluorescence was quantified using flow cytometry.

\section{FACS analysis of F-LPA4}

The ability of LPA4 to penetrate cells was tested by incubating fluorescein-labeled LPA4 with BT-20 cells (Figure 9). Fluorescein conjugate of LPA4 rapidly entered at each of the concentrations analyzed. The study showed a concentration-dependent pattern for cellular uptake of F-LPA4. Sodium azide inhibits energy-dependent cellular uptake. ${ }^{41}$ Endocytic cellular uptake is the major mechanism for some of the cell-penetrating peptides. ${ }^{3}$ The addition of sodium azide at high concentration of $77 \mathrm{mM}$ did not inhibit internalization of F-LPA4 (Figure 9). Therefore, the cellular uptake of F-LPA4 is not ATP dependent as it occurred in cells depleted of ATP. The mechanism of cellular uptake remains unclear. The distribution of basic and hydrophobic residues suggests that LPA4 is partly amphipathic. The amphipathic nature of the compound may be an important factor in the cellular uptake. The mechanism of cellular uptake for amphipathic peptides have been previously proposed. ${ }^{42}$ Most biomembranes are neutral at the outer surface and negative inside because of the presence of phospholipids bilayer. The translocation of the amphipathic peptide LPA4 through the plasma membrane is mediated possibly by interactions with the membrane lipids. These peptides have large hydrophobic spacers that are membrane-permeable. There is an inner hydrophobic layer between two outer hydrophilic surfaces in the membranes of cells. The cationic residues in LPA4 are required to improve the complex formation with hydrophilic negatively charged residues in the membrane. Cationic residues of LPA4 interact with negatively charged phospholipids in the plasma membrane. Arginine and lysine remain positively charged and are able to exert electrostatic binding. Subsequent interaction of the hydrophobic residues between LPA4 and the hydrophobic residues in membrane probably induces an encapsulation of LPA4 in the plasma membrane. After perturbation of lipid bilayer and reorganization of lipids, the peptide is released intracellularly.

Surprisingly in the presence of sodium azide, the cellular uptake was slightly higher at all tested concentrations when compared with that of in the absence of sodium azide. The mechanism of this observation is unknown, but could be due to reducing the electrostatic repulsion between positively charged residues in LPA4 and promoting interchain hydrophobic interactions, allowing more compounds to get into the cells. The observed increase of uptake was similar to that seen when the ionic strength was increased and cells were pretreated with other salts, such as $\mathrm{Na}_{2} \mathrm{HPO}_{4}, \mathrm{KCl}$, and $\mathrm{NaCl}$ as shown later. 


\section{Cellular uptake of F-GpYEEl in the presence of LPA4}

To further evaluate tripodal peptide transporters as potential agents for cell delivery, we sought to determine whether these agents could transport a phosphopeptide into the cells. The ability of LPA4 to enable cellular uptake of F-GpYEEI was determined by FACS analysis in BT-20 cells with an incubation time of $30 \mathrm{~min}$ at $37^{\circ} \mathrm{C}$. In this assay, F-GpYEEI displayed very limited cellular uptake when used alone (Figure 10).

As described above LPA1 is a peptide that showed weak binding and aggregation with phosphopeptides based on fluorescence polarization assays (see Figure 3). Therefore, LPA1 was used as a negative control in cellular uptake assays. In the presence of LPA1, there was no significant improvement in the cellular uptake of F-GpYEEI. In striking contrast, in the presence of LPA4 there was approximately 10 -fold higher cellular uptake of F-GpYEEI when compared with that of F-GpYEEI alone (Figure 10). The amphipathic nature of the tripodal peptide analogue appears to be essential in the molecular transporter property. LPA1 did not efficiently translocate F-GpYEEI into cells. Therefore, the presence of several positively charged moieties on a molecular scaffold is not the only required structural element for molecular transporter property. The length of the linkers had a dramatic effect on aggregation. The cellular uptake of F-GpYEEI was improved by increasing the number of spacer units between positively charged groups in the molecular transporter as shown in LPA4 when compared with that of LPA1. Thus, in addition to the positively charged groups, the hydrophobicity and/or conformational mobility of designed transporters also plays a role in cellular uptake. These results are consistent with binding data between LPA analogues and FGpYEEI. By increasing hydrophobicity and/or the conformational freedom of the backbone of peptides through addition of longer linkers, a significant enhancement in the binding of LPAs to F-GpYEEI was seen (Figure 2).

Furthermore, when fluorescein-labeled GYEEI, a control peptide without the phosphate group, was used, there was no cellular uptake in the presence or absence of tripodal peptides, LPA1 and LPA4 (Figure 10). These data indicate the cellular uptake of F-GpYEEI by LPA4 also requires electrostatic interactions between negatively charged phosphate in the cargo and the positively charged functional group on the tripodal peptide. In general, the amphipathic property of the tripodal peptide is essential for cellular delivery of the phosphopeptides.

The results on fixed cells and FACS analysis were not based on artificial uptake of peptides and false results. First, in addition to repeated washing steps preceding FACS analysis, trypsin was added to remove peptides associated with the plasma membrane. This step prevents false results associated with fixed cells in flow cytometry. Trypsin treatment is a known procedure to eliminate any false reports. ${ }^{3,43}$ Second, control experiments such as using LPA1 and FGYEEI were used. There was no cellular uptake using these compounds, confirming the cellular uptake is only selective for F-GpYEEI in the presence of LPA4. Finally, the cellular uptake of F-LPA4 in the live BT-20 cells was concentration dependent (see Figure S1 in Supporting Information). Furthermore, the cellular uptake assays with F-GpYEEI, FGpYTKM, and F-AMpYSSV were carried out in the presence and absence of LPA1 and LPA4 in live BT-20 cells (see Figure S2 in Supporting Information). The results were consistent with the results in the trypsinized fixed cells. LPA4 was able to deliver F-GpYEEI 5-fold higher when compared to those of F-GpYTKM and F-AMpYSSV. These data suggest the selective cellular uptake of F-GpYEEI in the presence of LPA4. Therefore, fixing was not causing any false results in our experiments, since the control compounds under similar conditions did not show any uptake and similar experiments in live cells showed consistent results. 


\section{Conformational analysis of LPA4 in the presence and absence of F-GpYEEI}

To provide a better insight about the secondary structures of LPA4 and LPA4-phosphopeptide conjugate, a conformational study based on circular dichroism (CD) was performed.

Amphipathicity of LPA4 may depend on the conformation of the peptide, with probably all cationic residues pointing to one direction and the hydrophobic residues on the opposite side; therefore, an ordered secondary structure is expected. Indeed, LPA4 adopted an ordered secondary structure, presumably because of self-association. The CD spectrum of LPA4 is characterized by a single minimum lying at $210 \mathrm{~nm}$, indicative of the existence of a partly $\beta$ structure. The peptide showed a concentration-dependent CD spectrum (Figure 11a).

Upon the addition of F-GpYEEI $(>10 \mu \mathrm{M})$ to the constant concentration of LPA4 $(50 \mu \mathrm{M})$, the CD spectrum was blue shifted (Figure 11b). For example with F-GpYEEI at $20 \mu \mathrm{M}$, the position of minimum is centered near $203 \mathrm{~nm}$ that is lower than that for peptides in pure $\beta$ sheet structures $(217 \mathrm{~nm})$. All spectra were corrected for background by subtraction of appropriate blanks, such as F-GpYEEI alone. These results suggest that the charge interactions of LPA4 with F-GpYEEI induce formation of a mixture of various structures possibly by encapsulation of phosphopeptide by the tripodal peptide. These structures still maintain an ordered secondary structure with the conformations partly based on a $\beta$-sheet conformation.

\section{The effect of ionic strength on cellular uptake of F-GpYEEl in the presence of LPA4}

The precise mechanism of LPA4 cellular delivery system remains unknown. The amphipathic property of LPA4 appears to play an important role in transporting F-GpYEEI into cells. Based on the several control experiments explained above, a combination of electrostatic and hydrophobic interactions is required for successful cellular uptake by LPA4. To provide better insights about the mechanism of cellular uptake, the experiments were carried out by modifications of the medium. To test whether the ionic strength was a factor in transport of cation-rich transporters, fluorescently labeled peptide was incubated with the cells for $30 \mathrm{~min}$ in the presence of different salt solutions, $\mathrm{NaCl}(138 \mathrm{mM}), \mathrm{KCl}(141 \mathrm{mM})$, and $\mathrm{Na}_{2} \mathrm{HPO}_{4}(0.05$ $\mathrm{mM}$ or $0.1 \mathrm{mM})$. The cells were washed and analyzed by flow cytometry. When the assay was carried out in the presence of salt ions, the cellular uptake was increased by 3-6 fold (Figure 12). The mechanism of this observation is unknown. It is generally assumed that salt reduces the electrostatic repulsion between positive charges, and promotes interchain hydrophobic interactions. The hydrophobic residues become better packed into stronger networks in ionic solutions. It seems plausible that the addition of salt relaxes the electrostatic repulsions to allow better assembly of the hydrophobic network presumably because of self-association of hydrophobic faces of the amphipathic peptide. Thus, increasing the ionic strength enhanced the cellular uptake probably by enhancing the hydrophobic interactions between amphipathic peptides and cell membrane and reducing electrostatic repulsion between positive charges in LPA4. The ion pair complex of LPA4 and F-GpYEEI partitions into the lipid bilayer and migrate across by passive diffusion. The complex dissociates on the inner side of the membrane and the transporter and cargo enter the cytosol. Furthermore, salt ions may disrupt electrostatic interactions between negatively charged phospholipids in the membrane and positively charged residues in LPA4, allowing more tripodal peptide along with its cargo to get into the cells. Further studies are required to determine the mechanism of ionic strength on cellular uptake of F-GpYEEI.

\section{Cellular uptake of $d$ (TTTTTTTTTTTT) by LPA4}

To further investigate whether LPA4 can act as molecular transporter of other negatively charged molecules such as oligonucleotides, 5'-fluorescence-labeled d(TTTTTTTTTTTT) was incubated with the BT-20 cells in the presence and absence of peptides. Cellular uptake studies using LPA4 and a fluorescein-labeled 12-mer thymidine oligonucleotide showed only twofold improvement in cellular delivery. Although the flow cytometry studies showed a slightly 
higher uptake in the presence of LPA4 than that of in the absence of LPA4 (Figure 13), the difference was not dramatic when compared with the similar studies in the presence of FGpYEEI. Therefore, LPA4 does not appear to be a suitable carrier for transporting the oligonucleotide across the cell membrane.

\section{Conclusions}

We report the synthesis and evaluation of tripodal molecular transporters, which combine both the cationic and the lipophilic properties. Some of the tripodal peptides showed amphipathic properties. The binding of several tripodal peptides to phosphopeptide probes was evaluated using FP assays. In general, an increase in spacing between three positively charged amino acids in peptides led to an increase in binding and aggregation with F-GpYEEI. LPAs containing long chain hydrophobic linkers exhibited high FP intensity in the presence of specific phosphopeptides, suggesting the formation of complexes with less local mobility through combination of hydrophobic and electrostatic interactions. Fluorescently labeled tripodal peptide F-LPA4 was evaluated for their cellular uptake studies. The cellular uptake of F-LPA4 was not inhibited with high concentrations of sodium azide, an inhibitor of ATPmediated uptake, suggesting that the delivery of phosphopeptides by LPA-4 was not energy dependent. LPA4 was found to be an efficient molecular transporter of F-GpYEEI into the cells. Long, hydrophobic, and/or flexible spacing in the tripodal positively charged peptide resulted in the most effective transport into cells exceeding that of phosphopeptides. Cellular uptake studies suggested the potential of these compounds for the cellular delivery of phosphopeptides. Cellular internalization via these peptides do not need prior chemically covalent coupling. Further optimization of the peptides may provide specific molecular transporters for different phosphopeptides.

\section{Experimental Section}

\section{General Information}

All reactions were carried out in Bio-Rad polypropylene columns by shaking and mixing using a Glass-Col small tube rotator in dry conditions or on a PS3 automated peptide synthesizer (Rainin Instrument Co., Inc.) at room temperature unless otherwise stated. In general, all peptides were synthesized by the solid-phase synthesis strategy employing Fmoc-based chemistry and Fmoc- Fmoc-L-amino acid building blocks. HBTU and NMM in DMF were used as coupling and activating reagents, respectively. Fmoc-amino acid-Wang resins, trityl alcohol resin, ( $1 N$-Dde, $8 N \mathrm{Mmt}$-spermidine-4-yl)-carbonyl Wang resin, coupling reagents, and Fmoc-amino acid building blocks were purchased from Novabiochem. Other chemicals and reagents were purchased from Sigma-Aldrich Chemical Company (Milwaukee, WI, USA). Fmoc deprotection at each step was carried out using piperidine in DMF (20\%). A mixture of TFA/anisole/water (90:5:5) or TFA/DCM (50:50) was used for side chain deprotection of amino acids and cleavage of the synthesized peptides from the resin. Crude peptides were precipitated by addition of cold diethyl ether $\left(\mathrm{Et}_{2} \mathrm{O}\right)$, and were purified by preparative reversephase HPLC. The chemical structures of compounds were determined by a high-resolution PE Biosystems Mariner API time of flight electrospray mass spectrometer. 5'-Fluorescencelabeled d(TTTTTTTTTTTT) was purchased from Integrated DNA Technologies, Inc. and was desalted and purified.

\section{Chemistry}

2.1. Synthesis of Cyclic Peptide (CP)—Trityl alcohol resin (1, $165 \mathrm{mg}, 0.1 \mathrm{mmol}, 0.61$ $\mathrm{mmol} / \mathrm{g}$ ) was swelled in dry toluene $(5 \mathrm{~mL})$ for $10 \mathrm{~min}$. Acetyl chloride $(552 \mathrm{mg}, 0.5 \mathrm{~mL}, 7.0$ $\mathrm{mmol}$ ) was added dropwise to the swelled resin. The mixture was heated at $60^{\circ} \mathrm{C}$ for $3 \mathrm{~h}$. The solvents were drained and the resin was washed thoroughly with dry DCM $(50 \mathrm{~mL})$ to afford 
trityl chloride resin (2). Resin 2 was suspended in dry DCM $(5 \mathrm{~mL}) . N$ - $\alpha$-L-Fmoc-Glu( $\gamma$-OAll)$\mathrm{OH}(100 \mathrm{mg}, 0.25 \mathrm{mmol})$ was added in one portion, followed by DIPEA $(150 \mu \mathrm{L}, 1.1 \mathrm{mmol})$ to the suspension. The resulting mixture was mixed for $1.5 \mathrm{~h}$ at room temperature and the solvent was drained. The resin was washed extensively with $\mathrm{MeOH}(50 \mathrm{~mL})$ and DCM (50 $\mathrm{mL}$ ), and dried overnight under vacuum to yield $\mathbf{3}$. Resin $\mathbf{3}$ was subjected to Fmoc peptide chemistry as described above. The amino acids used in the sequence were Fmoc- $\mathrm{Arg}(\mathrm{Pbf})-\mathrm{OH}$, Fmoc- $\beta$-Ala-OH, Fmoc-Arg(Pbf)-OH, Fmoc- $\beta$-Ala-OH, and Fmoc-Lys(Boc)-OH, respectively, to yield 4 . The allyl group in 4 was deprotected by treatment with $\operatorname{Pd}\left(\mathrm{Ph}_{3} \mathrm{P}\right)_{4} /$ $\mathrm{CHCl}_{3} / \mathrm{AcOH} / \mathrm{NMM}$. Briefly, the resin was suspended in a mixture of $\mathrm{CHCl}_{3} / \mathrm{AcOH} / \mathrm{NMM}$ $(37: 2: 1,5 \mathrm{~mL}) . \mathrm{Pd}\left(\mathrm{Ph}_{3} \mathrm{P}\right)_{4}(360 \mathrm{mg}, 0.32 \mathrm{mmol})$ was added to the resulting suspension. The mixture was mixed for $3 \mathrm{~h}$ at room temperature and the resin was washed extensively with DMF $(50 \mathrm{~mL}), \mathrm{MeOH}(50 \mathrm{~mL})$, and DCM $(50 \mathrm{~mL})$, respectively. The $N$-terminal was deprotected using piperidine in DMF $(20 \%, 5 \mathrm{~mL})$ for $10 \mathrm{~min}$. The resin was washed with DMF (50 mL), MeOH $(50 \mathrm{~mL})$, and DCM $(50 \mathrm{~mL})$, respectively, dried completely, and then suspended in dry DMF $(5 \mathrm{~mL})$. The cyclization was carried out by adding HBTU (300 mg, 0.8 $\mathrm{mmol})$ and DIPEA $(300 \mu \mathrm{L})$. The mixture was mixed for $16 \mathrm{~h}$ at room temperature. The peptide was cleaved from the resin using TFA/anisole/water $(90: 5: 5,5 \mathrm{~mL})$ and precipitated using cold ether and purified by HPLC to yield CP.

${ }^{1} \mathrm{H} \mathrm{NMR}\left(\mathrm{D}_{2} \mathrm{O}, 400 \mathrm{MHz}, \delta \mathrm{ppm}\right): 4.48-4.38(\mathrm{~m}, \mathrm{CH \alpha}, 1 \mathrm{H}), 4.38-4.10(\mathrm{~m}, \mathrm{CH \alpha}, 2 \mathrm{H}), 4.04-3.94$ (m, $\mathrm{CH \alpha}, 1 \mathrm{H}), 3.60-3.34(\mathrm{~m}, 5 \mathrm{H}), 3.28-3.10(\mathrm{~m}, 5 \mathrm{H}), 3.10-2.76\left(\mathrm{~m}, \mathrm{CH}_{2} \mathrm{NH}, 10 \mathrm{H}\right), 2.60-2.36$ (m, $\left.\mathrm{CH}_{2} \mathrm{CO}, 6 \mathrm{H}\right), 1.85-1.28$ (m, $\left.\mathrm{CH}_{2}, 14 \mathrm{H}\right)$; HR-MS (ESI-TOF) $(\mathrm{m} / \mathrm{z})$ : $\mathrm{C}_{29} \mathrm{H}_{53} \mathrm{~N}_{13} \mathrm{O}_{8}$, calcd, 711.4297; found, $711.6298[\mathrm{M}]^{+}, 712.6330[\mathrm{M}+\mathrm{H}]^{+}, 356.9862[\mathrm{M}+\mathrm{H}]^{+2}, 238.6754[\mathrm{M}+$ $\mathrm{H}]^{+3}$.

\subsection{The Synthesis of Dendrimer Peptide Analogue (DPA)—( $1 \mathrm{~N}$-Dde, $8 \mathrm{~N}$-Mmt-} spermidine-4-yl)-carbonyl Wang resin ( $233 \mathrm{mg}, 0.1 \mathrm{mmol}, 0.43 \mathrm{mmol} / \mathrm{g}$ ) was suspended in DMF $(5 \mathrm{~mL})$ and was shaken for $10 \mathrm{~min}$. The solvent was drained and the resin was suspended again in DMF $(5 \mathrm{~mL})$ and shaken for additional $10 \mathrm{~min}$. The resin was then washed with DMF $(20 \mathrm{~mL}), \mathrm{MeOH}(20 \mathrm{~mL})$ and DCM $(20 \mathrm{~mL})$, respectively. For the deprotection of the Mmt group in 5, the resin was suspended in a mixture of TFE/DCM $(5 \mathrm{~mL}, 1: 1)$. HOBt $(76 \mathrm{mg}, 0.56$ $\mathrm{mmol}$ ) was added to the resulting suspension. The mixing was continued for $3 \mathrm{~h}$. The solvent was drained and the process was repeated once. The resin was washed extensively with DMF $(20 \mathrm{~mL}), \mathrm{MeOH}(20 \mathrm{~mL})$, and DCM $(20 \mathrm{~mL})$, respectively, and was dried completely under vacuum for the next step. The completely washed and dried resin was suspended in dry DMF ( $5 \mathrm{~mL}$ ), to which $N$ - $\alpha$-Fmoc-Lys(Dde)-OH ( $0.2 \mathrm{mmol}, 2 \mathrm{eq})$, HBTU (76 mg, $0.2 \mathrm{mmol}$ ), and DIPEA $(150 \mu \mathrm{L}, 1.1 \mathrm{mmol})$ were added. The resulting suspension was mixed for $30 \mathrm{~min}$ at room temperature. The solvent was drained and the resin was washed with DMF $(20 \mathrm{~mL})$. The coupling was repeated in another cycle for $1 \mathrm{~h}$. The resin was washed thoroughly using DMF $(20 \mathrm{~mL}), \mathrm{MeOH}(20 \mathrm{~mL})$, and DCM $(20 \mathrm{~mL})$, respectively, and dried under vacuum overnight to afford 6. Resin 6 was suspended in piperidine in DMF $(5 \mathrm{~mL}, 20 \%)$ and the suspension was mixed for $10 \mathrm{~min}$ to deprotect the Fmoc group. The solvent was drained and the process was repeated once. The resin was washed extensively with DMF $(20 \mathrm{~mL}), \mathrm{MeOH}(20 \mathrm{~mL})$, and DCM $(20 \mathrm{~mL})$, respectively. The resin was dried completely under vacuum for the next step. The coupling reaction with the second amino acid, $\mathrm{FmocNH}\left(\mathrm{CH}_{2}\right)_{4} \mathrm{COOH}$ was carried out using the conditions described above for Fmoc peptide synthesis to produce 7. Fmoc deprotection and coupling with $N$ - $\alpha$-Fmoc-Lys $(t \mathrm{Bu})-\mathrm{OH}$ in $\mathbf{7}$ afforded $\mathbf{8}$. Resin $\mathbf{8}$ was suspended in hydrazine monohydrate in DMF $(5 \mathrm{~mL}, 2 \%)$ and the suspension was mixed for $2 \mathrm{~min}$ to deprotect the Dde group. The solvent was drained and the process was repeated once. The resin was washed extensively with DMF $(20 \mathrm{~mL}), \mathrm{MeOH}(20 \mathrm{~mL})$, and DCM $(20 \mathrm{~mL})$, respectively, and dried completely under vacuum. Coupling reaction with $N-\alpha-F m o c-A r g(P b f)-$ $\mathrm{OH}$ using the conditions described above for Fmoc peptide synthesis afforded 9 . Fmoc group 
was deprotected as described above. The peptide was cleaved from the resin using TFA/DCM (50:50), precipitated using cold ether, and purified by HPLC to yield DPA.

${ }^{1} \mathrm{H}$ NMR $\left(\mathrm{D}_{2} \mathrm{O}, 400 \mathrm{MHz}, \delta \mathrm{ppm}\right): 4.23(\mathrm{t}, J=8.00, \mathrm{CH \alpha} \mathrm{Arg}, 1 \mathrm{H}), 4.09(\mathrm{t}, J=8.00 \mathrm{~Hz}$,

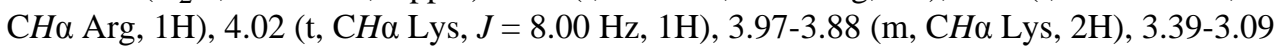
(m, $\left.\mathrm{CH}_{2} \mathrm{NH}, 12 \mathrm{H}\right), 3.06-3.00\left(\mathrm{~m}, \mathrm{CH}_{2} \mathrm{NH}, 4 \mathrm{H}\right), 2.95\left(\mathrm{t}, J=8.00 \mathrm{~Hz}, \mathrm{CH}_{2} \mathrm{NH}, 2 \mathrm{H}\right), 2.32-2.24$ (m, $\left.\mathrm{CH}_{2} \mathrm{CO}, 2 \mathrm{H}\right), 2.00-1.82(\mathrm{~m}, 8 \mathrm{H}), 1.78-1.24\left(\mathrm{~m}, \mathrm{CH}_{2}, 26 \mathrm{H}\right)$; HR-MS (ESI-TOF) $(\mathrm{m} / \mathrm{z}$ ): $\mathrm{C}_{36} \mathrm{H}_{76} \mathrm{~N}_{16} \mathrm{O}_{5}$, calcd, 812.6185 ; found, $429.431\left[\mathrm{C}_{19} \mathrm{H}_{43} \mathrm{~N}_{9} \mathrm{O}_{2}\right]^{2+}, 407.9538[\mathrm{M}+2 \mathrm{H}]^{2+}$, $329.9330\left[\mathrm{C}_{15} \mathrm{H}_{33} \mathrm{~N}_{6} \mathrm{O}_{2}\right]^{2+}$.

2.3. General Procedure for the Synthesis of LPAs_LPAs were synthesized by the solid-phase Fmoc-based chemistry using Fmoc-Arg(pbf)-Wang resin or Fmoc-Lys(Boc)Wang resin as starting amino acids. Fmoc-L-amino acid building blocks included FmocNH $\left(\mathrm{CH}_{2}\right)_{11} \mathrm{COOH}$, FmocNH$\left(\mathrm{CH}_{2}\right)_{4} \mathrm{COOH}$, FmocNH$\left(\mathrm{CH}_{2}\right)_{5} \mathrm{COOH}$, Fmoc-Lys(Boc)-OH, and Fmoc-Arg(Pbf)-OH. HBTU and NMM in $N, N$-dimethylformamide (DMF) were used as coupling and activating reagents, respectively. Fmoc deprotection at each step was carried out by using piperidine in DMF (20\%). A mixture of TFA/anisole/water (90:5:5) was used for side chain deprotection of amino acids and cleavage of the synthesized peptides from the resin. Crude peptides were precipitated by addition of cold diethyl ether $\left(\mathrm{Et}_{2} \mathrm{O}\right)$ and purified by reverse phase HPLC. The synthesis of LPA8 is shown as a representative example in Scheme 3 starting from Arg-attached Wang resin. The chemical structures of compounds were determined by a high-resolution electrospray time of flight electrospray mass spectrometer.

LPA1: ${ }^{1} \mathrm{H}$ NMR $\left(\mathrm{D}_{2} \mathrm{O}, 400 \mathrm{MHz}, \delta \mathrm{ppm}\right): 4.34-4.24(\mathrm{~m}, \mathrm{CH \alpha}$ Arg, $1 \mathrm{H}), 4.08(\mathrm{t}, J=8.00 \mathrm{~Hz}$, $\mathrm{CH} \alpha \mathrm{Arg}, 1 \mathrm{H}), 3.88(\mathrm{t}, J=8.00 \mathrm{~Hz}, \mathrm{CH} \alpha \mathrm{Lys}, 1 \mathrm{H}), 3.30-3.06\left(\mathrm{~m}, \mathrm{CH}_{2} \mathrm{NH}, 8 \mathrm{H}\right), 2.91(\mathrm{t}, J=$ $\left.8.00 \mathrm{~Hz}, \mathrm{CH}_{2} \mathrm{NH}, 2 \mathrm{H}\right), 2.32-2.18\left(\mathrm{~m}, \mathrm{CH}_{2} \mathrm{CO}, 4 \mathrm{H}\right), 1.92-1.80(\mathrm{~m}, 3 \mathrm{H}), 1.76-1.26\left(\mathrm{~m}, \mathrm{CH}_{2}\right.$, 20H); HR-MS (ESI-TOF) $(\mathrm{m} / \mathrm{z})$ : $\left[\mathrm{C}_{28} \mathrm{H}_{56} \mathrm{~N}_{12} \mathrm{O}_{6}\right]$ calcd, 656.4446; found, $656.8206[\mathrm{M}]^{+}$, $657.8174[\mathrm{M}+\mathrm{H}]^{+}, 329.5605[\mathrm{M}+\mathrm{H}]^{+2}, 220.3718[\mathrm{M}+\mathrm{H}]^{+3}$.

LPA2: ${ }^{1} \mathrm{H}$ NMR $\left(\mathrm{D}_{2} \mathrm{O}, 400 \mathrm{MHz}, \delta \mathrm{ppm}\right): 4.34-4.26(\mathrm{~m}, \mathrm{CH \alpha} \mathrm{Arg}, 1 \mathrm{H}), 4.11(\mathrm{t}, J=8.00 \mathrm{~Hz}$, $\mathrm{CH} \alpha \mathrm{Arg}, 1 \mathrm{H}), 3.86(\mathrm{t}, J=8.00 \mathrm{~Hz}, \mathrm{CH} \alpha$ Lys $1 \mathrm{H}), 3.26-3.06\left(\mathrm{~m}, \mathrm{CH}_{2} \mathrm{NH}, 8 \mathrm{H}\right), 2.92$ (t, $J=8.00$ $\left.\mathrm{Hz}, \mathrm{CH}_{2} \mathrm{NH}, 2 \mathrm{H}\right), 2.34-2.20$ (m, $\left.\mathrm{CH}_{2} \mathrm{CO}, 4 \mathrm{H}\right), 1.94-1.80(\mathrm{~m}, 3 \mathrm{H}), 1.76-1.30\left(\mathrm{~m}, \mathrm{CH}_{2}, 20 \mathrm{H}\right)$; HR-MS (ESI-TOF) $(\mathrm{m} / \mathrm{z})$ : [ $\left.\mathrm{C}_{28} \mathrm{H}_{56} \mathrm{~N}_{12} \mathrm{O}_{6}\right]$ calcd, 656.4446; found, $656.8410[\mathrm{M}]^{+}, 657.8492$ $[\mathrm{M}+\mathrm{H}]^{+}, 658.8268[\mathrm{M}+2 \mathrm{H}]^{+}, 329.5687[\mathrm{M}+\mathrm{H}]^{+2}, 220.3805[\mathrm{M}+\mathrm{H}]^{+3}$.

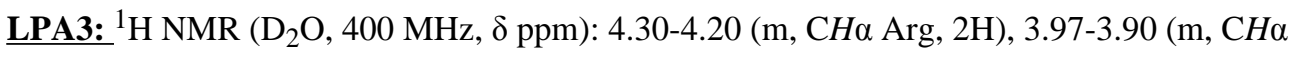
Lys, $1 \mathrm{H}), 3.32-3.02\left(\mathrm{~m}, \mathrm{CH}_{2} \mathrm{NH}, 8 \mathrm{H}\right), 2.93\left(\mathrm{t}, J=8.00 \mathrm{~Hz}, \mathrm{CH}_{2} \mathrm{NH}, 2 \mathrm{H}\right), 2.32-2.17(\mathrm{~m}$, $\left.\mathrm{CH}_{2} \mathrm{CO}, 4 \mathrm{H}\right), 1.92-1.80(\mathrm{~m}, 3 \mathrm{H}), 1.78-1.30\left(\mathrm{~m}, \mathrm{CH}_{2}, 20 \mathrm{H}\right)$; HR-MS (ESI-TOF) $(\mathrm{m} / \mathrm{z})$ : $\left[\mathrm{C}_{28} \mathrm{H}_{56} \mathrm{~N}_{12} \mathrm{O}_{6}\right]$ calcd, 656.4446; found, $656.8931[\mathrm{M}]^{+}, 657.9010[\mathrm{M}+\mathrm{H}]^{+}, 658.9078[\mathrm{M}+$ $2 \mathrm{H}]^{+}, 329.5875[\mathrm{M}+\mathrm{H}]^{+2}, 220.3914[\mathrm{M}+\mathrm{H}]^{+3}$.

LPA4: ${ }^{1} \mathrm{H}$ NMR ( $\left.\mathrm{D}_{2} \mathrm{O}, 400 \mathrm{MHz}, \delta \mathrm{ppm}\right): 4.31-4.19$ (m, $\mathrm{CH \alpha}$ Arg, $2 \mathrm{H}$ ), 3.94-3.88 (m, $\mathrm{CH \alpha}$ Lys, $1 \mathrm{H}), 3.24-3.04\left(\mathrm{~m}, \mathrm{CH}_{2} \mathrm{NH}, 8 \mathrm{H}\right), 2.93\left(\mathrm{t}, J=8.00 \mathrm{~Hz}, \mathrm{CH}_{2} \mathrm{NH}, 2 \mathrm{H}\right), 2.30-2.18(\mathrm{~m}$, $\left.\mathrm{CH}_{2} \mathrm{CO}, 4 \mathrm{H}\right), 1.92-1.80(\mathrm{~m}, 3 \mathrm{H}), 1.78-1.30\left(\mathrm{~m}, \mathrm{CH}_{2}, 20 \mathrm{H}\right), 1.30-1.10\left(\mathrm{~m}, \mathrm{CH}_{2}, 28 \mathrm{H}\right)$; HR-MS (ESI-TOF) (m/z): [ $\mathrm{C}_{42} \mathrm{H}_{84} \mathrm{~N}_{12} \mathrm{O}_{6}$ ] calcd, 852.6637; found, $852.4374[\mathrm{M}]^{+}, 853.4413[\mathrm{M}+$ $\mathrm{H}]^{+}, 854.4363[\mathrm{M}+2 \mathrm{H}]^{+}, 427.4579[\mathrm{M}+\mathrm{H}]^{+2}, 285.6866[\mathrm{M}+\mathrm{H}]^{+3}$.

LPA5: ${ }^{1} \mathrm{H}$ NMR $\left(\mathrm{D}_{2} \mathrm{O}, 400 \mathrm{MHz}, \delta \mathrm{ppm}\right): 4.34-4.24(\mathrm{~m}, \mathrm{CH \alpha}$ Arg, $1 \mathrm{H}), 4.16(\mathrm{t}, J=8.00 \mathrm{~Hz}$, $\mathrm{CH \alpha \textrm {Arg }}, 1 \mathrm{H}), 3.90(\mathrm{t}, J=8.00 \mathrm{~Hz}, \mathrm{CH} \alpha \mathrm{Lys}, 1 \mathrm{H}), 3.26-3.00\left(\mathrm{~m}, \mathrm{CH}_{2} \mathrm{NH}, 8 \mathrm{H}\right), 2.96-2.86(\mathrm{~m}$, $\left.\mathrm{CH}_{2} \mathrm{NH}, 2 \mathrm{H}\right), 2.34-2.16\left(\mathrm{~m}, \mathrm{CH}_{2} \mathrm{CO}, 4 \mathrm{H}\right), 1.96-1.80(\mathrm{~m}, 3 \mathrm{H}), 1.76-1.34\left(\mathrm{~m}, \mathrm{CH}_{2}, 20 \mathrm{H}\right)$, 1.30-1.10 (m, $\left.\mathrm{CH}_{2}, 28 \mathrm{H}\right)$; HRMS (ESI-TOF) $(\mathrm{m} / \mathrm{z})$ : $\left[\mathrm{C}_{42} \mathrm{H}_{84} \mathrm{~N}_{12} \mathrm{O}_{6}\right]$ calcd, 852.6637; found, $852.4181[\mathrm{M}]^{+}, 853.4208[\mathrm{M}+\mathrm{H}]^{+}, 854.9599[\mathrm{M}+2 \mathrm{H}]^{+}, 427.4429[\mathrm{M}+\mathrm{H}]^{+2}, 285.6863[\mathrm{M}$ $+\mathrm{H}]^{+3}$. 
LPA6: ${ }^{1} \mathrm{H}$ NMR $\left(\mathrm{D}_{2} \mathrm{O}, 400 \mathrm{MHz}, \delta \mathrm{ppm}\right): 4.36-4.26(\mathrm{~m}, \mathrm{CH \alpha}$ Arg, $1 \mathrm{H}), 4.18(\mathrm{t}, J=8.00 \mathrm{~Hz}$, $\mathrm{CH} \alpha \mathrm{Arg}, 1 \mathrm{H}), 3.92(\mathrm{t}, J=8.00 \mathrm{~Hz}, \mathrm{CH} \alpha \mathrm{Lys}, 1 \mathrm{H}), 3.32-3.04\left(\mathrm{~m}, \mathrm{CH}_{2} \mathrm{NH}, 8 \mathrm{H}\right), 3.00-2.86(\mathrm{~m}$, $\left.\mathrm{CH}_{2} \mathrm{NH}, 2 \mathrm{H}\right), 2.32-2.16\left(\mathrm{~m}, \mathrm{CH}_{2} \mathrm{CO}, 4 \mathrm{H}\right), 1.94-1.80(\mathrm{~m}, 3 \mathrm{H}), 1.78-1.30\left(\mathrm{~m}, \mathrm{CH}_{2}, 20 \mathrm{H}\right)$, 1.30-1.13 (m, $\mathrm{CH}_{2}, 28 \mathrm{H}$ ); HR-MS (ESI-TOF) $(\mathrm{m} / \mathrm{z})$ : [ $\left.\mathrm{C}_{42} \mathrm{H}_{84} \mathrm{~N}_{12} \mathrm{O}_{6}\right]$ calcd, 852.6637; found, $852.4475[\mathrm{M}]^{+}, 853.4585[\mathrm{M}+\mathrm{H}]^{+}, 854.4402[\mathrm{M}+2 \mathrm{H}]^{+}, 427.4549[\mathrm{M}+\mathrm{H}]^{+2}, 285.6664[\mathrm{M}$ $+\mathrm{H}]^{+3}$.

LPA7: ${ }^{1} \mathrm{H}$ NMR $\left(\mathrm{D}_{2} \mathrm{O}, 400 \mathrm{MHz}, \delta \mathrm{ppm}\right): 4.33-4.25(\mathrm{~m}, \mathrm{CH \alpha}$ Arg, $1 \mathrm{H}), 4.25-4.15$ (m, $\mathrm{CH} \alpha$ Arg, $1 \mathrm{H}), 3.89$ (t, $J=8.00 \mathrm{~Hz}, \mathrm{CH \alpha}$ Lys, $1 \mathrm{H}), 3.25-3.00\left(\mathrm{~m}, \mathrm{CH}_{2} \mathrm{NH}, 12 \mathrm{H}\right), 2.95-2.85(\mathrm{~m}$, $\left.\mathrm{CH}_{2} \mathrm{NH}, 2 \mathrm{H}\right), 2.30-2.17\left(\mathrm{~m}, \mathrm{CH}_{2} \mathrm{CO}, 4 \mathrm{H}\right), 2.17-2.10\left(\mathrm{~m}, \mathrm{CH}_{2} \mathrm{CO}, 4 \mathrm{H}\right), 1.90-1.80(\mathrm{~m}, 3 \mathrm{H})$, $1.75-1.30\left(\mathrm{~m}, \mathrm{CH}_{2}, 28 \mathrm{H}\right), 1.30-1.03\left(\mathrm{~m}, \mathrm{CH}_{2}, 32 \mathrm{H}\right)$; HR-MS (ESI-TOF) $(\mathrm{m} / \mathrm{z})$ :

$\left[\mathrm{C}_{54} \mathrm{H}_{106} \mathrm{~N}_{14} \mathrm{O}_{8}\right]$ calcd, 1078.8318; found, $1078.8075[\mathrm{M}]^{+}, 540.2233[\mathrm{M}+\mathrm{H}]^{+2}, 360.8998$ $[\mathrm{M}+\mathrm{H}]^{+3}$.

LPA8: ${ }^{1} \mathrm{H}$ NMR ( $\left.\mathrm{D}_{2} \mathrm{O}, 400 \mathrm{MHz}, \delta \mathrm{ppm}\right): 4.31-4.24$ (m, $\left.\mathrm{CH \alpha} \mathrm{Arg}, 1 \mathrm{H}\right), 4.18-4.10$ (m, $\mathrm{CH \alpha}$ Arg, $1 \mathrm{H}), 3.89(\mathrm{t}, J=8.00 \mathrm{~Hz}, \mathrm{CH} \alpha \mathrm{Lys}, 1 \mathrm{H}), 3.28-3.01\left(\mathrm{~m}, \mathrm{CH}_{2} \mathrm{NH}, 12 \mathrm{H}\right), 2.96-2.86(\mathrm{~m}$, $\left.\mathrm{CH}_{2} \mathrm{NH}, 2 \mathrm{H}\right), 2.30-2.06\left(\mathrm{~m}, \mathrm{CH}_{2} \mathrm{CO}, 8 \mathrm{H}\right), 1.92-1.80(\mathrm{~m}, 3 \mathrm{H}), 1.78-1.32\left(\mathrm{~m}, \mathrm{CH}_{2}, 28 \mathrm{H}\right)$, 1.30-1.05 (m, $\left.\mathrm{CH}_{2}, 32 \mathrm{H}\right)$; HR-MS (ESI-TOF) $(\mathrm{m} / \mathrm{z})$ : $\left[\mathrm{C}_{54} \mathrm{H}_{106} \mathrm{~N}_{14} \mathrm{O}_{8}\right]$ calcd, 1078.8318; found, $1078.8078[\mathrm{M}]^{+}, 540.2269[\mathrm{M}+\mathrm{H}]^{+2}, 360.9058[\mathrm{M}+\mathrm{H}]^{+3}$.

LPA9: ${ }^{1} \mathrm{H}$ NMR $\left(\mathrm{D}_{2} \mathrm{O}, 400 \mathrm{MHz}, \delta \mathrm{ppm}\right): 4.28-4.21$ (m, $\left.\mathrm{CH} \alpha \mathrm{Arg}, 1 \mathrm{H}\right), 4.20-4.14(\mathrm{~m}, \mathrm{CH} \alpha$ Arg, $1 \mathrm{H}), 3.90$ ((t, $J=8.00 \mathrm{~Hz}, \mathrm{CH \alpha}$ Lys, $1 \mathrm{H}), 3.28-3.02\left(\mathrm{~m}, \mathrm{CH}_{2} \mathrm{NH}, 12 \mathrm{H}\right), 2.98-2.88(\mathrm{~m}$, $\left.\mathrm{CH}_{2} \mathrm{NH}, 2 \mathrm{H}\right), 2.28-2.08\left(\mathrm{~m}, \mathrm{CH}_{2} \mathrm{CO}, 8 \mathrm{H}\right), 1.90-1.80(\mathrm{~m}, 3 \mathrm{H}), 1.80-1.32\left(\mathrm{~m}, \mathrm{CH}_{2}, 28 \mathrm{H}\right)$, 1.30-1.00 (m, $\left.\mathrm{CH}_{2}, 32 \mathrm{H}\right)$; HR-MS (ESI-TOF) $(\mathrm{m} / \mathrm{z})$ : $\left[\mathrm{C}_{54} \mathrm{H}_{106} \mathrm{~N}_{14} \mathrm{O}_{8}\right]$ calcd, 1078.6103 ; found, $1078.8078[\mathrm{M}]^{+}, 540.1669[\mathrm{M}+\mathrm{H}]^{+2}, 360.8712[\mathrm{M}+\mathrm{H}]^{+3}$.

\subsection{Synthesis of the Fluorescent Peptide Probes}

2.4.1.5-Carboxyfluorescein Succinimidyl Ester: To a solution of 5-carboxyfluorescein (150 $\mathrm{mg}, 0.40 \mathrm{mmol})$ in anhydrous DMF $(1.5 \mathrm{~mL})$ was added 1-[3-(dimethylamino)propyl]-3ethylcarbodiimide hydrochloride (EDAC; $93.6 \mathrm{mg}, 0.49 \mathrm{mmol}$ ) followed by $N$ -

hydroxysuccinimide (HOSu; $57.4 \mathrm{mg}, 0.50 \mathrm{mmol}$ ). The flask was covered with foil and the solution stirred under nitrogen for $4.5 \mathrm{~h}$. After $4.5 \mathrm{~h}$, additional EDAC (15.6 mg, $0.08 \mathrm{mmol}$ ) was added and the reaction stirred under nitrogen overnight. The reaction mixture was rinsed into a separatory funnel with a minimal amount of DMF and diluted with acetone $(6.0 \mathrm{~mL})$. K-phosphate buffer $(0.1 \mathrm{M}, \mathrm{pH} 6,7.5 \mathrm{~mL})$ was added and the mixture was extracted with $\mathrm{Et}_{2} \mathrm{O} /$ ethyl acetate $(\mathrm{EtOAc})(2: 1,9.0 \mathrm{~mL})$. The organic layer was separated and the aqueous layer extracted two times with $\mathrm{Et}_{2} \mathrm{O} / \mathrm{EtOAc}(2: 1,7.5 \mathrm{~mL})$. The combined organic extracts were washed with water $(3 \times 6.0 \mathrm{~mL})$ and brine $(1 \times 7.5 \mathrm{~mL})$, respectively, dried over $\mathrm{Na}_{2} \mathrm{SO}_{4}$, and filtered. The organic solvents were removed in vacuo. A residue was dissolved in $2.0 \mathrm{~mL}$ acetonitrile and purified by HPLC. The spectroscopic data were identical with those reported in literature. 40

\subsubsection{Coupling Reaction of the Peptide-Attached Resins with 5-Carboxyfluorescein} Succinimidyl Ester: The fluorescent probes were synthesized according to the previously reported procedure. ${ }^{39}, 40$ In summary, the peptide-attached resins and DIPEA $(850 \mu \mathrm{L}, 6.1$ $\mathrm{mmol}$ ) were added to a solution of 5-carboxyfluorescein succinimidyl ester (250 mg, 0.53 $\mathrm{mmol})$ in anhydrous DMF $(5.0 \mathrm{~mL})$. The mixtures were stirred for $48 \mathrm{~h}$ at room temperature. The resins were filtered, washed with DMF $(100 \mathrm{~mL})$, and cleaved using a solution of TFA/ water/triisopropyl silane ( $5.0 \mathrm{~mL}: 0.5 \mathrm{~mL}: 0.5 \mathrm{~mL}$ ) for $2.5 \mathrm{~h}$. The filtrates were collected, concentrated, precipitated from cold ether, and the crude products were purified by preparative reverse-phase HPLC. F-GpYEEI has been synthesized previously. ${ }^{39,40}$ The compounds were characterized by a high-resolution electrospray time of flight electrospray mass spectrometer. 
HR-MS (ESI-TOF) ( $\mathrm{m} / \mathrm{z}$ ): Fluorescein-Ala-Met-pTyr-Ser-Ser-Val (F-AMpYSSV) $\mathrm{C}_{49} \mathrm{H}_{55} \mathrm{~N}_{6} \mathrm{O}_{19} \mathrm{PS}$ calcd, 1094.2980; found, $1095.5000[\mathrm{M}+1]^{+}, 736.4097[\mathrm{M}-$ fluorescein $]^{+}$; Fluorescein-pTyr-Thr-Lys-Met (F-GpYTKM) $\mathrm{C}_{47} \mathrm{H}_{53} \mathrm{~N}_{6} \mathrm{O}_{17} \mathrm{PS}$ calcd, 1036.2926; found, $1035.3250[\mathrm{M}-1]^{+}, 621.7533$ [M- fluorescein $\left.-\mathrm{G}\right]^{+}$; Fluorescein-pTyrThr-Ser-Met (F-GpYTSM) $\mathrm{C}_{44} \mathrm{H}_{46} \mathrm{~N}_{5} \mathrm{O}_{18} \mathrm{PS}$ calcd, 995.5572; found, $995.2296[\mathrm{M}]^{+}$; Fluorescein-Gly-pSer-Glu-Glu-Ile (FGpSEEI) $\mathrm{C}_{42} \mathrm{H}_{46} \mathrm{~N}_{5} \mathrm{O}_{20} \mathrm{P}$ calcd, 971.2474; found, $970.5358[\mathrm{M}-1]^{+}, 613.7610$ [M - fluorescein $]^{+}, 387.1952[\mathrm{M}$ - fluorescein - GpS] Fluorescein-Gly-Tyr-Glu-Glu-Ile (F-GYEEI) $\mathrm{C}_{48} \mathrm{H}_{49} \mathrm{~N}_{5} \mathrm{O}_{17}$ calcd, 967.3124; found,

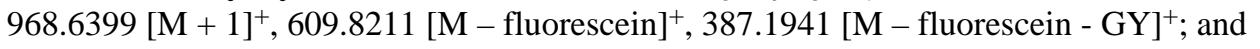
Fluorescein-Gly-pTyr-Ala-Ala-Ile (F-GpYAAI) $\mathrm{C}_{44} \mathrm{H}_{46} \mathrm{~N}_{5} \mathrm{O}_{16} \mathrm{P}$ calcd, 931.26772 ; found, $930.7029[\mathrm{M}]^{+}$.

2.5. Synthesis of F-LPA4-The fluorescent probe was synthesized by coupling of 5carboxyfluorescein succinimidyl ester with a Wang resin-bound peptide containing the LPA-4 sequence and a glycine linker (12). Resin $12(0.1 \mathrm{mmol})$ and DIPEA $(850 \mu \mathrm{l}, 6.1 \mathrm{mmol})$ were added to a solution of 5-carboxyfluorescein succinimidyl ester $(250 \mathrm{mg}, 0.53 \mathrm{mmol})$ in anhydrous DMF $(5.0 \mathrm{~mL})$. The mixture was stirred for $48 \mathrm{~h}$ at room temperature. The resin was filtered, washed with DMF $(100 \mathrm{~mL})$, and cleaved using a solution of TFA/water/ triisopropyl silane ( $5.0 \mathrm{~mL}: 0.5 \mathrm{~mL}: 0.5 \mathrm{~mL}$ ) for $2.5 \mathrm{~h}$. The filtrate was collected, concentrated, precipitated from cold ether, and the crude product was purified by preparative reverse-phase HPLC. The chemical structure of F-LP4 was determined by a high-resolution electrospray time of flight electrospray mass spectrometer. HR-MS (ESI-TOF) (m/z): F-LPA4 $\mathrm{C}_{65} \mathrm{H}_{97} \mathrm{~N}_{13} \mathrm{O}_{13}$ calcd, 1267.7329, found, $1265.8769[\mathrm{M}-2 \mathrm{H}]^{+}, 634.3520[\mathrm{M}]^{2+}, 423.6989[\mathrm{M}+\mathrm{H}]^{3+}$.

\section{Binding Assays}

Binding assays against the fluorescent probes were carried out using a fluorescent polarization (FP) assay. FP intensities were measured at $25^{\circ} \mathrm{C}$ in a disposable glass tube (volume $600 \mu \mathrm{L}$ ) using a Perkin Elmer LS 55 luminescence spectrometer equipped with an FP apparatus. The excitation and emission wavelengths were set at 485 and $535 \mathrm{~nm}$, respectively. For the assays, final concentrations of $80 \mathrm{nM}$ fluorescent probe, phosphate buffer $(20 \mathrm{mM}, \mathrm{pH} 7.3,100 \mathrm{mM}$ $\mathrm{NaCl}, 2 \mathrm{mM}$ DTT, $0.1 \% \mathrm{BSA}$ ), water, and various concentrations (0-0.5 mM) of each peptide were used. The order of addition to each glass tube $(600 \mu \mathrm{L})$ was (i) buffer, (ii) water, (iii) fluorescent probe, and (iv) tripodal peptide. A background control (without the peptide) was used. The fluorescence intensities of fluorescent probe interacting with the tripodal peptides was calculated by the following equation:

$$
\text { Fluorescence intensity }=\mathrm{FP}_{\mathrm{s}}-\mathrm{FP}_{\mathrm{bgd}}
$$

where $\mathrm{FP}_{\mathrm{S}}$ is the fluorescent polarization value of the sample containing the peptide, and $\mathrm{FP}_{\mathrm{bgd}}$ is the fluorescent polarization value of the background control (buffer + water + probe). The fluorescence intensities of the various concentrations of the assayed peptides were plotted. The reported values are the mean of three separate determinations with a standard deviation of less than $5 \%$.

\section{Cellular Uptake Assay}

\subsection{Fluorescence Microscopy}

4.1.1. Fluorescence Microscopy of F-LPA4 in BT-20 Cells (Figure 5) and Fluorescence Microscopy of F-GpYEEI in the Presence of LPA4 in MDA-MB-468 Cells (Figure 6): The cellular uptake studies and intracellular localization of F-LPA4 and LPA4 + F-GpYEEI was imaged using fluorescence microscopy. The human breast carcinoma xenograft cells [MDA-MB-468 (ATCC \# HTB-132) or BT-20 (ATCC \# HTB-19)] were grown on circular glass coverslips in 6-well culture plates having modified Eagle's medium (EMEM). Upon 
reaching about $70 \%$ confluency, they were washed once with serum-free media (SFM) followed by incubation with a solution of F-LPA4 (or LPA4 + F-GpYEEI) $(10 \mu \mathrm{M}$ for each solution in SFM prepared from stock solution in DMSO) in different periods (5, 10, 30 and 60 $\min )$. At the end of each incubation time-point, the cells were washed twice with phosphate buffered saline (PBS, pH 7.4) and fixed using ice-cold primary cell fixative (1:1 mixture of glutaraldehyde: formaldehyde, $4 \%$ aqueous solution). The cells were mounted on glass slides with cell-side down using Fluormount medium and edges were sealed with a resin solution. They were observed under fluorescent microscope under FITC channel (480/520 nm).

4.1.2. Real Time Fluorescence Microscopy in Live BT-20 Cells (Figure 7): The cellular uptake studies and intracellular localization of LPA4 + F-GpYEEI were imaged using ZEISS Axioplan 2 light microscope equipped with transmitted light microscopy with differentialinterference contrast method and an Achroplan 40X objective. The human breast carcinoma cells BT-20 (ATCC \# HTB-19) were grown on $25 \mathrm{~cm}^{2}$ cell culture flasks with Eagle's Minimum Essential Medium (EMEM) with 10\% fetal bovine serum. Upon reaching about 70\% confluency, they were washed once with serum-free media (SFM) followed by incubation with a solution of $10 \mu \mathrm{M}$ of F-GpYEEI alone or with $50 \mu \mathrm{M}$ of LPA1 or LPA4, and incubated for $30 \mathrm{~min}$ at $37^{\circ} \mathrm{C}$. They were then observed under fluorescent microscope under brightfield and FITC channels $(480 / 520 \mathrm{~nm})$.

4.2. Semi-Quantitative Estimation of Cellular Uptake of LPA4-BT-20 cells were seeded in 96-well plates at a density of 10,000 cells per well with EMEM. They were allowed to adhere and grow for 24 hours. The medium was replaced with SFM and graded concentrations $(5,10,25,50,100 \mu \mathrm{M})$ of the LPA4 and incubated for $24 \mathrm{~h}$. The cells were washed twice with PBS (pH 7.4) and EMEM was added before measuring the fluorescent intensity $(480 / 520 \mathrm{~nm})$ using a plate reader. Eight wells were used per concentration. The blank was the group of cells that received only SFM. Percentage increase in fluorescent intensity was calculated against the control.

\subsection{Flow Cytometry}

4.3.1. General Information: All of the stock peptide solutions were prepared in DMSO and diluted 1000 times to make the final concentration before using. The human breast carcinoma cells BT-20 (ATCC\# HTB-19) were grown on $25 \mathrm{~cm}^{2}$ cell culture flasks with Eagle's Minimum Essential Medium (EMEM) with 10\% fetal bovine serum. Upon reaching about $70 \%$ confluency, the cells were treated as described below and incubated for $30 \mathrm{~min}$ at $37^{\circ} \mathrm{C}$. Then they were washed twice with serum-free medium followed by treating with $0.25 \%$ trypsin/ $/ 0.53$ $\mathrm{mM}$ EDTA at $37{ }^{\circ} \mathrm{C}$ for $5 \mathrm{~min}$ and washed with $1 \mathrm{~mL}$ PBS $(\mathrm{pH}=7.4)$ at $2500 \mathrm{rpm}$ for $5 \mathrm{~min}$. The cells were then fixed in cold $75 \%$ ethanol for $30 \mathrm{~min}$ at $-20^{\circ} \mathrm{C}$ followed by washing twice with $1 \mathrm{~mL}$ PBS and spinning at $2500 \mathrm{rpm}$ and the supernatant was carefully discarded to avoid cell loss. Then the cells were analyzed by Flow Cytometry (FACSCalibur: Becton Dickinson) using FITC channel and CellQuest software. The data presented are based on the mean fluorescence signal for 5000 cells collected. All the assays were done in triplicate.

4.3.2. Cellular Uptake of F-GpYEEI or F-LPA-4 at Different Concentrations: Upon the cells reaching about $70 \%$ confluency, the medium was replaced with $2 \mathrm{~mL}$ serum-free medium and $2 \mu \mathrm{L}$ of graded concentrations $(0,1.25,2.5,5,10$ and $20 \mathrm{mM}$ in DMSO) of F-GpYEEI or F-LPA-4. Then the assays were performed as described in General Information.

4.3.3. Cellular Uptake of F-LPA-4 with Sodium Azide: The assays were performed as previously described in 4.3.2 with the exception that the cells used were preincubated for 30 min with $0.5 \%$ sodium azide $(77 \mathrm{mM}$ ) in EMEM before the addition of F-LPA4. The uptake assays were run in parallel in the presence and absence of sodium azide. 
4.3.4. Cellular Uptake Assay of F-GpYEEI and F-GYEEI in the Presence of LPA-1 and LPA-4: Upon the cells reaching about 70\% confluency, the medium was replaced with $2 \mathrm{~mL}$ serum-free medium with DMSO as control and $10 \mu \mathrm{M}$ of F-GpYEEI or F-GYEEI with $50 \mu \mathrm{M}$ of LPA-1 or LPA-4, and incubated for $30 \mathrm{~min}$ at $37^{\circ} \mathrm{C}$. Then the assays were performed as described in General Information.

4.3.5. Cellular Uptake Assay of F-GpYEEI in the Presence of LPA-1 and LPA-4 and Salt Ions: $\mathrm{NaCl}$ and $\mathrm{KCl}$ were prepared. The assays were performed as described in 4.3 .2 with the exception that salt ions solutions were used instead of EMEM.

4.3.6. Cellular Uptake Assay of F-GpYEEI in the Presence of LPA-4 in Sodium Hydrogen Phosphate Solutions: Upon the cells reaching about $70 \%$ confluency, the medium was replaced with $2 \mathrm{~mL}$ of different concentrations of sodium hydrogen phosphate $(0 \mathrm{mg} / \mathrm{L}, 12.5$ $\mathrm{mg} / \mathrm{L}$ and $25 \mathrm{mg} / \mathrm{L}$ of $\mathrm{Na}_{2} \mathrm{HPO}_{4}$ in EMEM) and $10 \mu \mathrm{M} \mathrm{F-GpYEEI} \mathrm{with} 50 \mu \mathrm{M}$ of LPA-4. Then the assays were performed as described in General Information.

\section{Cell Viability Assay}

Upon the cells reaching about $70 \%$ confluency, the medium was replaced with $2 \mathrm{~mL}$ serumfree medium with DMSO as control, F-GpYEEI $(10 \mu \mathrm{M})$, F-LPA-4 $(10 \mu \mathrm{M})$, F-GpYEEI $(10$ $\mu \mathrm{M})$ with LPA-1 $(50 \mu \mathrm{M})$, or F-GpYEEI $(10 \mu \mathrm{M})$ with LPA-4 $(50 \mu \mathrm{M})$, and incubated for 30 min at $37{ }^{\circ} \mathrm{C}$. Then the cells were treated with $0.25 \%$ trypsin $/ 0.53 \mathrm{mM}$ EDTA at $37{ }^{\circ} \mathrm{C}$ for 5 $\mathrm{min}$. Both of the supernatant and the detached cells were collected and centrifuged at $2500 \mathrm{rpm}$ for $5 \mathrm{~min}$. The cell pellets were then suspended in $1 \mathrm{~mL}$ serum-free medium and analyzed using Vi-Cell Cell Viability Analyzer (Beckman Coulter) (triplicate assay).

\section{Circular Dichroism (CD) Spectroscopy}

All CD spectra were recorded in $1 \mathrm{~cm}$ path length cylindrical cells on a nitrogen-flushed JASCO J-810 spectropolarimeter interfaced with a $25^{\circ} \mathrm{C}$ water bath by averaging 3 consecutive scans. All spectra were recorded with a $4 \mathrm{sec}$ response and a band width of $1 \mathrm{~nm}$. CD spectra were measured with the spectropolarimeter using a $50 \mathrm{~nm} \cdot \mathrm{min}^{-1}$ scan speed. All spectra were corrected for background by subtraction of appropriate blanks. The data are represented in the 190-260 nm spectral range.

\section{Supplementary Material}

Refer to Web version on PubMed Central for supplementary material.

\section{Acknowledgment}

We acknowledge the financial support from National Center for Research Resources, NIH, Grant Number 1 P20 RR16457.

\section{REFERENCES}

1. Langel, U. Handbook of Cell-Penetrating Peptides. Boca Raton, FL: CRC Press; 2007.

2. El-Andaloussi S, Holm T, Langel U. Cell-penetrating peptides: Mechanisms and applications. Curr. Pharm. Des 2005;11:3597-3611. [PubMed: 16305497]

3. Fotin-Mleczek M, Fischer R, Brock R. Endocytosis and cationic cell-penetrating peptides - a merger of concepts and methods. Curr. Pharm. Des 2005;11:3613-3628. [PubMed: 16305498]

4. Fernandez-Carneado J, Kogan MJ, Pujals S, Giralt E. Amphipathic peptides and drug delivery. Biopolymers (Pept. Sci.) 2004;76:196-203.

5. Deshayes S, Morris MC, Divita G, Heitz F. Cell-penetrating peptides: Tools for intracellular delivery of therapeutics. Cell. Mol. Life. Sci 2005;62:1839-1849. [PubMed: 15968462] 
6. Stiriba SE, Frey H, Haag R. Dendritic polymers in biomedical applications: From potential to clinical use in diagnostics and therapy. Angew. Chem. Int. Ed. Engl 2002;41:1329-1334.

7. Wimmer N, Marano RJ, Kearns PS, Rakoczy EP, Toth I. Syntheses of polycationic dendrimers on lipophilic peptide core for complexation and transport of oligonucleotides. Bioorg. Med. Chem. Lett 2002;12:2635-2637. [PubMed: 12182876]

8. Aoki S, Kimura E. Recent progress in artificial receptors for phosphate anions in aqueous solution. Reviews in Molecular Biotechnol 2002;90:129-155.

9. Rothbard JB, Kreider E, VanDeusen CL, Wright L, Wylie BL, Wender PA. Arginine-rich molecular transporters for drug delivery: role of backbone spacing in cellular uptake. J. Med. Chem 2002;45:3612-3618. [PubMed: 12166934]

10. Fischer PM, Krausz E, Lane DP. Cellular delivery of impermeable effector molecules in the form of conjugates with peptides capable of mediating membrane translocation. Bioconjugate Chem 2001;12:825-841.

11. Lindgren ME, Haellbrink MM, Elmquist AM, Langel U. Passage of cell-penetrating peptides across a human epithelial cell layer in vitro. Biochemical J 2004;377:69-76.

12. Frankel AD, Pabo CO. Cellular uptake of the tat protein from human immunodeficiency virus. Cell 1988;55:1189-1193. [PubMed: 2849510]

13. Bhorade R, Weissleder R, Nakakoshi T, Moore A, Tung C-H. Macrocyclic chelators with paramagnetic cations are internalized into mammalian cells via a HIV-Tat derived membrane translocation peptide. Bioconjugate Chem 2000;11:301-305.

14. Josephson L, Tung CH, Moore A, Weissleder R. High-efficiency intracellular magnetic labeling with novel superparamagnetic-Tat peptide conjugates. Bioconjugate Chem 1999;10:186-191.

15. Fawell S, Seery J, Daikh Y, Moore C, Chen LL, Pepinsky B, Barsoum J. Tat-mediated delivery of heterologous proteins into cells. Proc. Natl. Aca. Sci. U.S.A 1994;91:664-668.

16. Mitchell DJ, Kim DT, Steinman L, Fathman CG, Rothbard JB. Polyarginine enters cells more efficiently than other polycationic homopolymers. J. Peptide Res 2000;56:318-325. [PubMed: 11095185]

17. Futaki S, Suzuki T, Ohashi W, Yagami T, Tanaka S, Ueda K, Sugiura Y. Arginine-rich peptides: an abundant source of membrane-permeable peptides having potential as carriers for intracellular protein delivery. J. Biol. Chem 2001;276:5836-5840. [PubMed: 11084031]

18. Wender PA, Mitchell DJ, Pattabiraman K, Pelkey ET, Steinman L, Rothbard JB. The design, synthesis, and evaluation of molecules that enable or enhance cellular uptake: peptoid molecular transporters. Proc. Natl. Acad. Science U.S.A 2000;97:13003-13008.

19. Wender PA, Jessop TC, Pattabiraman K, Pelkey ET, VanDeusen CL. An efficient, scalable synthesis of the molecular transporter octaarginine via a segment doubling strategy. Org. Lett 2001;3:32293232. [PubMed: 11594801]

20. Umezawa N, Gelman MA, Haigis MC, Raines RT, Gellmann SH. Translocation of a $\beta$-peptide across cell membranes. J. Am. Chem. Soc 2002;124:368-369. [PubMed: 11792194]

21. Rueping M, Mahajan Y, Sauer M, Seebach D. Cellular uptake studies with $\beta$-peptides. ChemBioChem 2002;3:257-259. [PubMed: 11921409]

22. Wender PA, Rothbard JB, Jessop TC, Kreider EL, Wylie BL. Oligocarbamate molecular transporters: Design, synthesis, and biological evaluation of a new class of transporters for drug delivery. J. Am. Chem. Soc 2002;124:13382-13383. [PubMed: 12418880]

23. Futaki S, Niwa M, Nakase I, Tadokoro A, Zhang Y, Nagaoka M, Wakako N, Sugiura Y. Arginine carrier peptide bearing $\mathrm{Ni}$ (II) chelator to promote cellular uptake of histidine-tagged proteins. Bioconjugate Chem 2004;15:475-481.

24. Rothbard JB, Jessop TC, Lewis RS, Murray BA, Wender PA. Role of membrane potential and hydrogen bonding in the mechanism of translocation of guanidinium-rich peptides into cells. J. Am. Chem. Soc 2004;126:9506-9507. [PubMed: 15291531]

25. Gras-Masse H. Lipid vector for the delivery of peptides towards intracellular pharmacological targets. J. Mol. Recognit 2003;16:234-239. [PubMed: 14523934]

26. Trehin R, Merkle HP. Chances and pitfalls of cell penetrating peptides for cellular drug delivery. Eur. J. Pharm. Biopharm 2004;58:209-223. [PubMed: 15296950] 
27. Songyang Z, Shoelson SE, Chaudhuri M, Gish G, Pawson T, Haser WG, King F, Roberts T, Ratnofsky S, Lechleider RJ, Neel BG, Birge RB, Fajardo JE, Chou MM, Hanafusa H, Schaffhausen B, Cantley LC. SH2 domains recognize specific phosphopeptide sequences. Cell 1993;72:767-778. [PubMed: 7680959]

28. Burke TR, Yao Z-J, Liu D-G, Voigt J, Gao Y. Phosphoryltyrosyl mimetics in the design of peptidebased signal transduction inhibitors. Biopolymers 2001;60:32-44. [PubMed: 11376431]

29. Eck MJ. A new flavor in phosphotyrosine recognition. Structure 1995;3:421-424. [PubMed: 7545066]

30. Pinna LA, Donella-Deana A. Phosphorylated synthetic peptides as tools for studying protein phosphatases. Biochim. et Biophys. Acta, Molecular Cell Research 1994;1222:415-431.

31. Ottinger EA, Shekels LL, Bernlohr DA, Barany G. Synthesis of phosphotyrosine-containing peptides and their use as substrates for protein tyrosine phosphatases. Biochemistry 1993;32:4354-4361. [PubMed: 7682846]

32. Zhou Y, Abagyan R. How and why phosphotyrosine-containing peptides bind to the SH2 and PTB domains. Fold. Des 1998;3:513-522. [PubMed: 9889165]

33. Machida K, Mayer BJ. The SH2 domain: versatile signaling module and pharmaceutical target. Biochim. et Biophys. Acta, Proteins and Proteomics 2005;1747:1-25.

34. Dunican DJ, Doherty P. Designing cell-permeant phosphopeptides to modulate intracellular signaling pathways. Biopolymers 2001;60:45-60. [PubMed: 11376432]

35. Williams EJ, Dunican DJ, Green PJ, Howell FV, Derossi D, Walsh FS, Doherty P. Selective inhibition of growth factor-stimulated mitogenesis by a cell-permeable Grb2-binding peptide. J. Biol. Chem 1997;272:22349-22354. [PubMed: 9268386]

36. Derossi D, Williams EJ, Green PJ, Dunican DJ, Doherty P. Stimulation of mitogenesis by a cellpermeable PI 3-kinase binding peptide. Biochem. Biophys. Res. Commun 1998;251:148-152. [PubMed: 9790922]

37. Theodore L, Derossi D, Chassaing G, Llirbat B, Kubes M, Jordan P, Chneiweiss H, Godement P, Prochiantz A. Intraneuronal delivery of protein kinase $\mathrm{C}$ pseudosubstrate leads to growth cone collapse. J. Neurosci 1995;15:7158-7167. [PubMed: 7472470]

38. Waksman G, Kominos D, Robertson SC, Pant N, Baltimore D, Birge RB, Cowburn D, Hanafusa H, Mayer BJ, Overduin M, Resh MD, Rios CB, Silverman L, Kuriyan J. Crystal structure of the phosphotyrosine recognition domain $\mathrm{SH} 2$ of v-src complexed with tyrosine-phosphorylated peptides. Nature 1992;358:646-653. [PubMed: 1379696]

39. Nam N-H, Ye G, Sun G, Parang K. Conformationally constrained peptide analogues of pTyr-GluGlu-Ile as inhibitors of the Src SH2 domain binding. J. Med. Chem 2004;47:3131-3141. [PubMed: 15163193]

40. Lynch BA, Loiacono KA, Tiong CL, Adams SE, MacNeil IA. A fluorescence polarization based SrcSH2 binding assay. Anal. Biochem 1997;247:77-82. [PubMed: 9126374]

41. Sandvig K, Olsnes S. Entry of the toxic proteins abrin, modeccin, ricin, and diphtheria toxin into cells. II. Effect of $\mathrm{pH}$, metabolic inhibitors, and ionophores and evidence for toxin penetration from endocytotic vesicles. J. Biol. Chem 1982;257:7504-7513. [PubMed: 7085634]

42. Derossi D, Calvet S, Trembleau A, Brunissen A, Chassaing G, Prochintz A. Cell internalization of the third helix of the Antennapedia homeodomain is receptor-independent. J. Biol. Chem 1996;271:18188-18193. [PubMed: 8663410]

43. Fischer R, Waizenegger T, Kohler K, Brock R. A quantitative validation of fluorophore-labelled cellpermeable peptide conjugates: fluorophore and cargo dependence of import. Biochim. et Biophys. Acta, Biomembranes 2002;1564:365-374.

\section{Abbreviations}

LPAs, linear peptide analogues; F-GpYEEI, fluorescein-labeled GpYEEI; F-LPA4, fluorescein-attached LPA4; pTyr, phosphotyrosine; CP, cyclic peptide; DPA, dendrimer peptide analogue; FP, fluorescence polarization; FACS, fluorescence-activated cell sorter; CD, circular dichroism. 

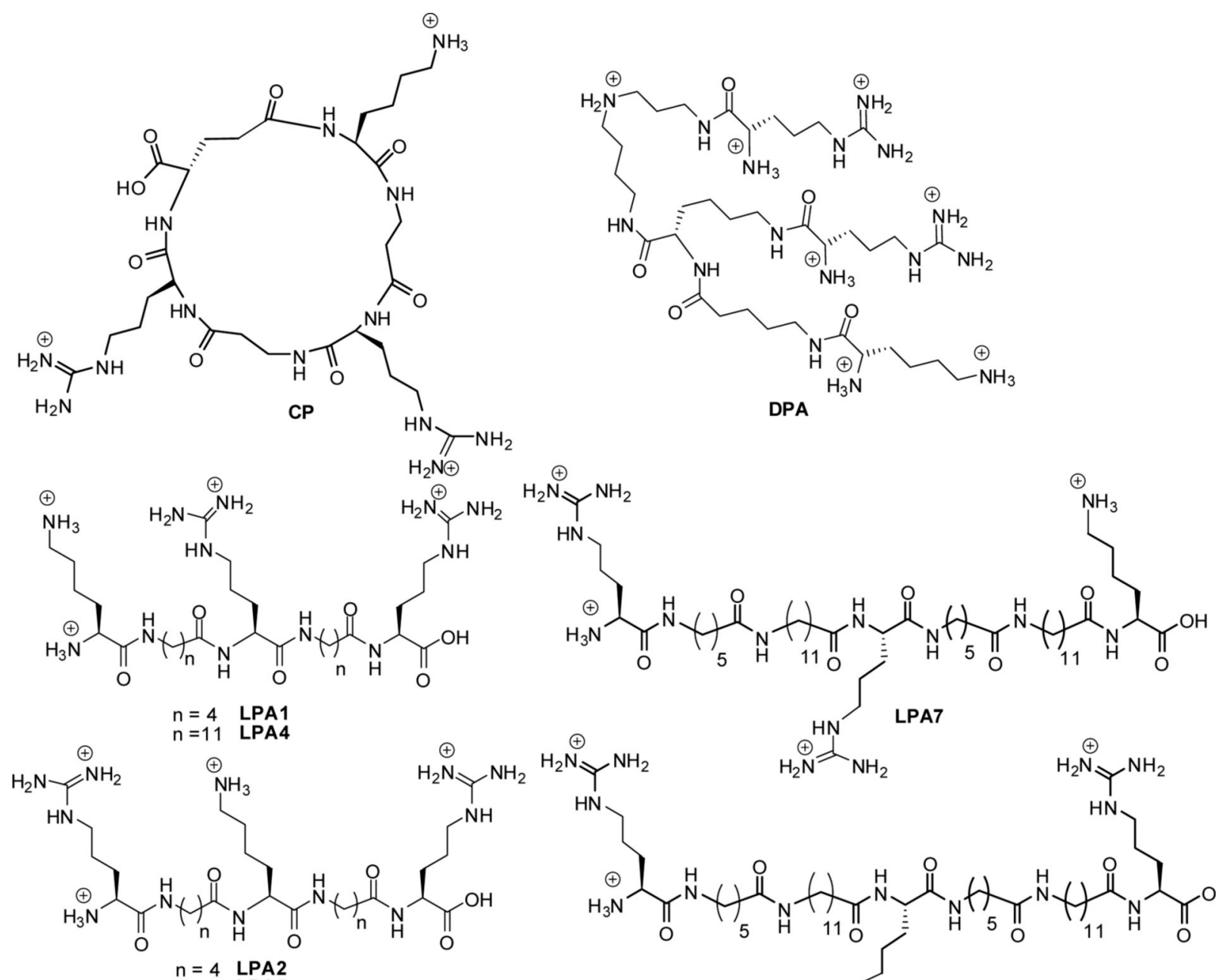

$\mathrm{H}_{2} \stackrel{\oplus}{\mathrm{N}} \mathrm{Y}^{\mathrm{NH}_{2}}$
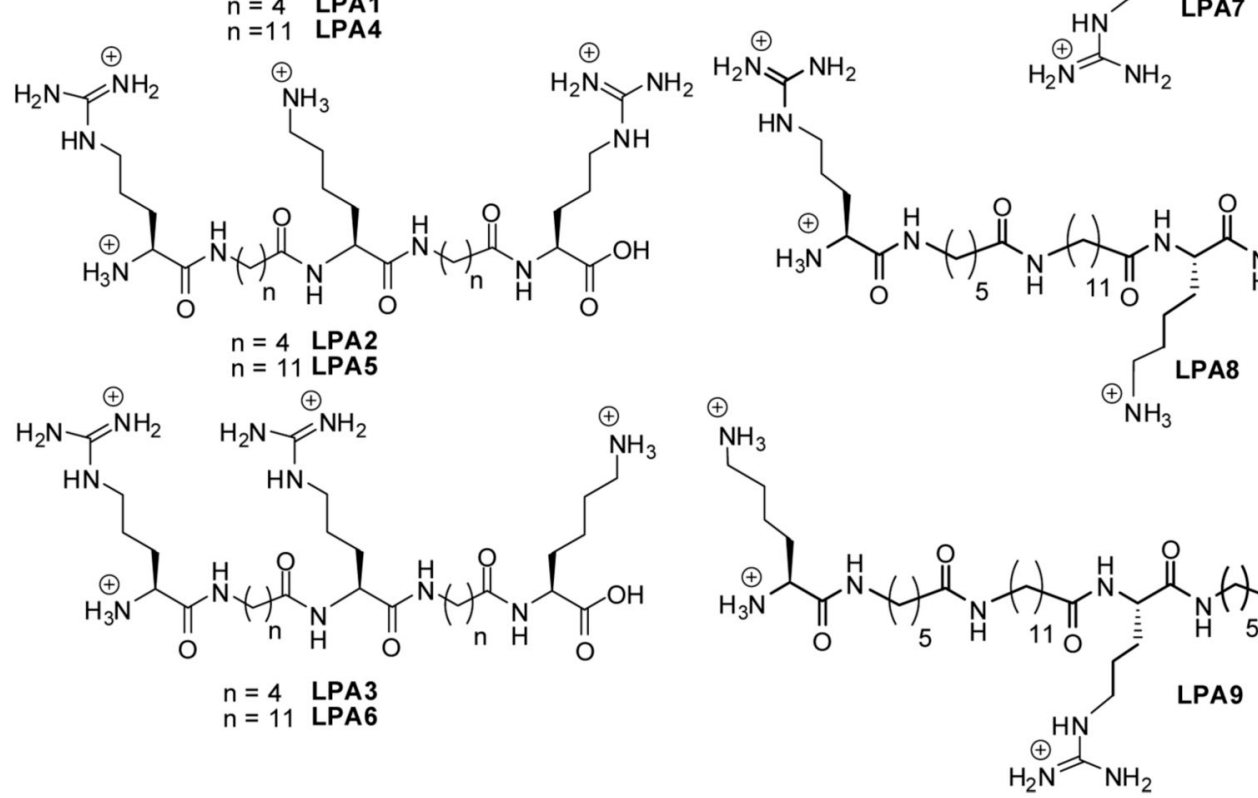

Figure 1.

Synthesized tripodal positively charged peptide analogues. 


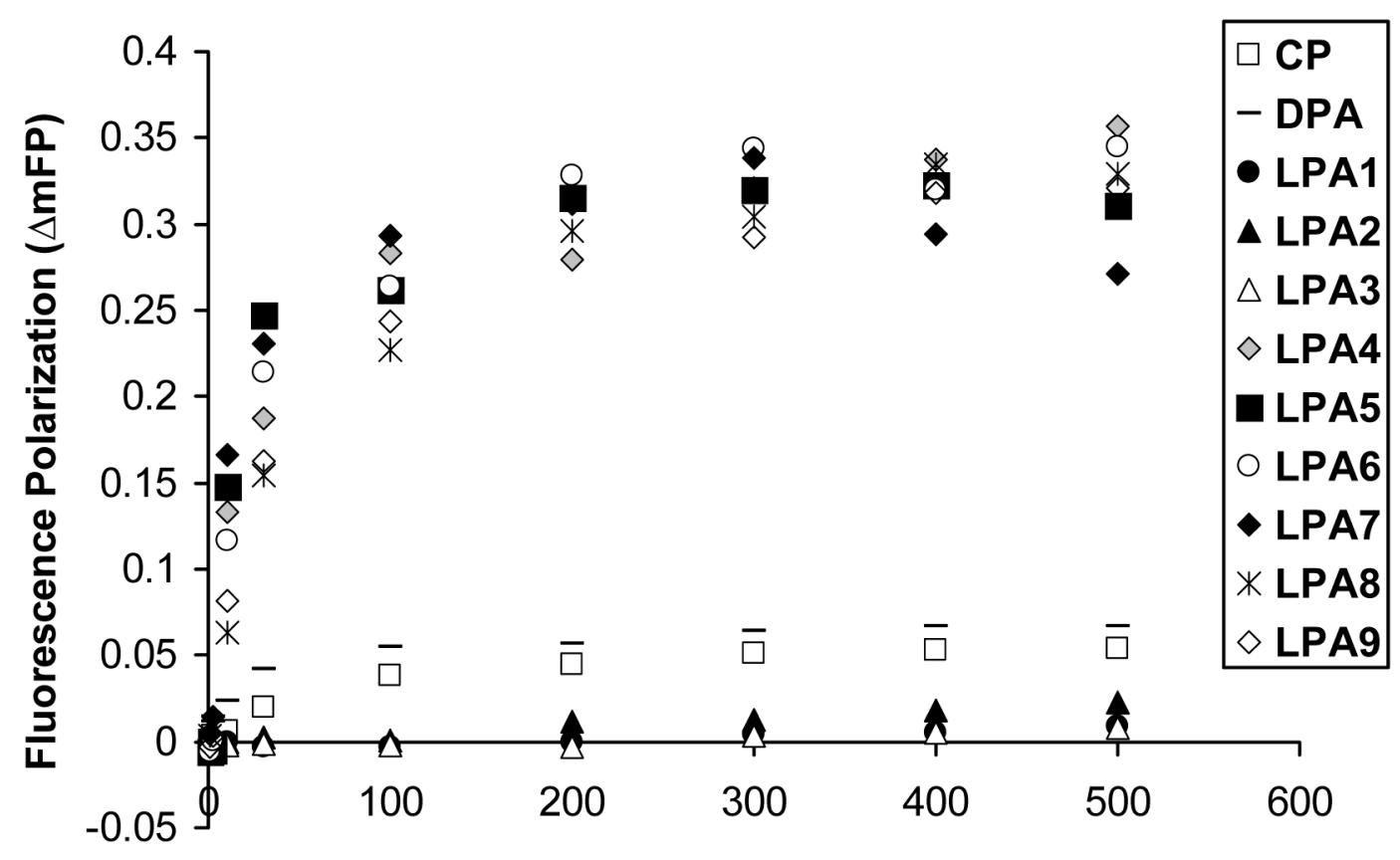

Tripodal Peptide Analogues Concentration $(\mu \mathrm{M})$

Figure 2.

The FP binding assays of the peptide analogues in the presence of F-GpYEEI $(80 \mathrm{nM})$. 


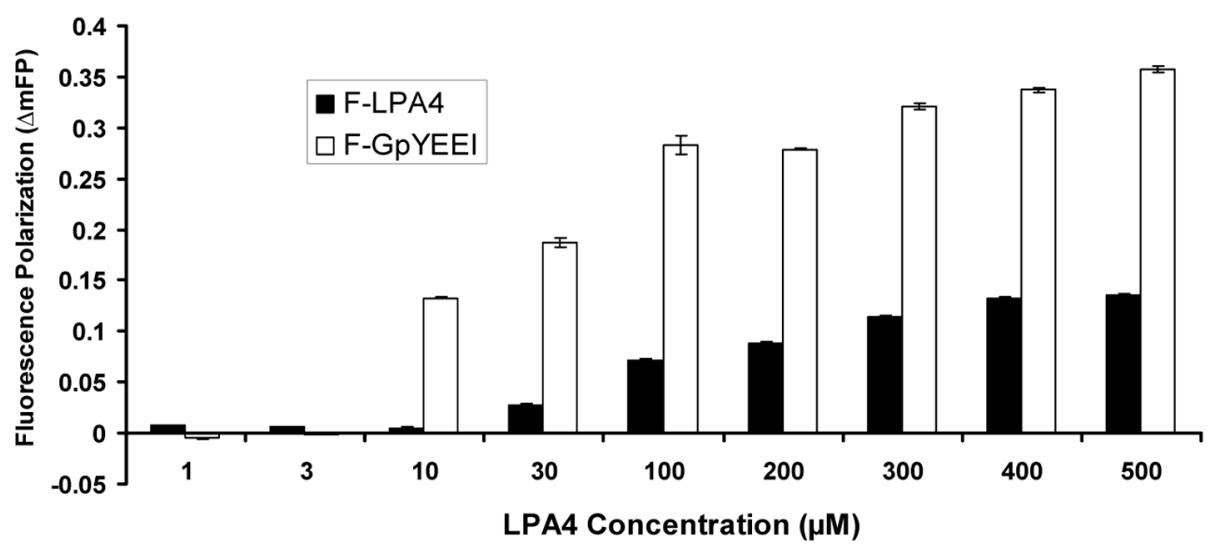

Figure 3.

The FP binding assay of LPA4 in the presence of F-GpYEEI (80 nM) or F-LPA4 (80 nM). 

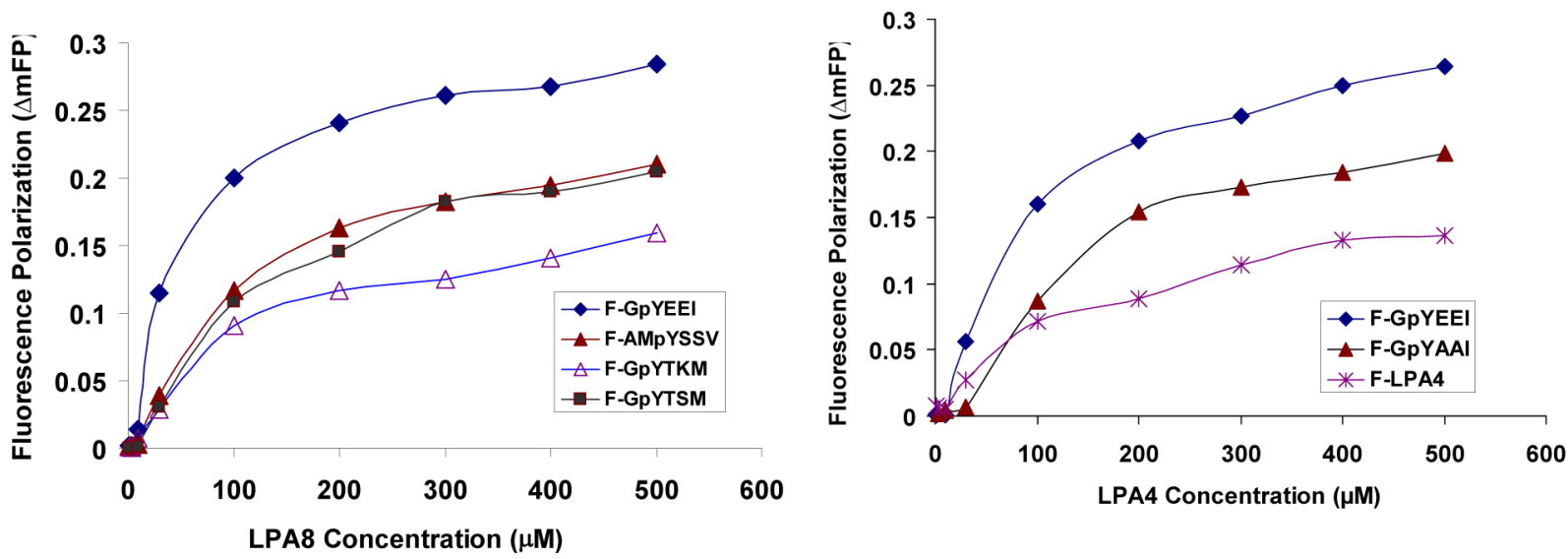

Figure 4.

Selectivity of LPA8 and LPA4 toward the fluorescence-attached peptide probes (80 nM). FGpYEEI was used as a control. 

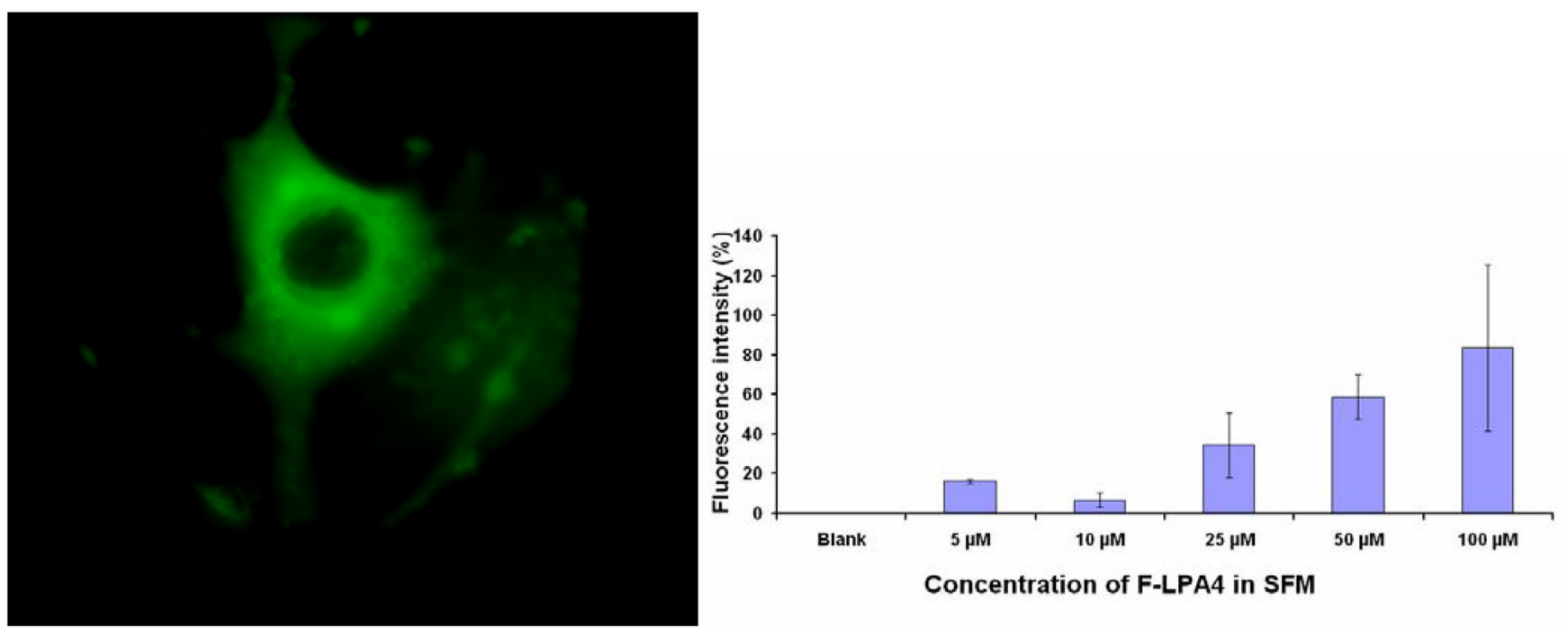

Figure 5.

The cellular uptake of F-LPA4 represented by fluorescence intensity in cytosol in BT-20 cells (left); The fluorescence intensity and therefore the cellular uptake of F-LPA4 $(5-100 \mu \mathrm{M})$ were concentration-dependent (right). 


\begin{tabular}{|c|c|c|c|c|}
\hline MDA-MB-468 Cell & Only F-GpYEEI & Only F-GpYEEI & F-GpYEEI + LPA4 & F-GpYEEI + LPA4 \\
\hline $30 \mathrm{~min}$ & 10 min & 30 min & $10 \mathrm{~min}$ & 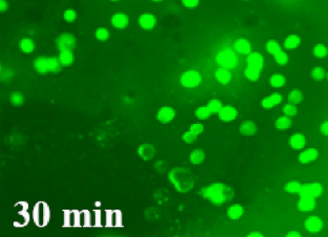 \\
\hline
\end{tabular}

Figure 6.

Cellular uptake assay of LPA4 $(10 \mu \mathrm{M})$ and F-GpYEEI $(10 \mu \mathrm{M})$ using MDA-MB-468 cells. 

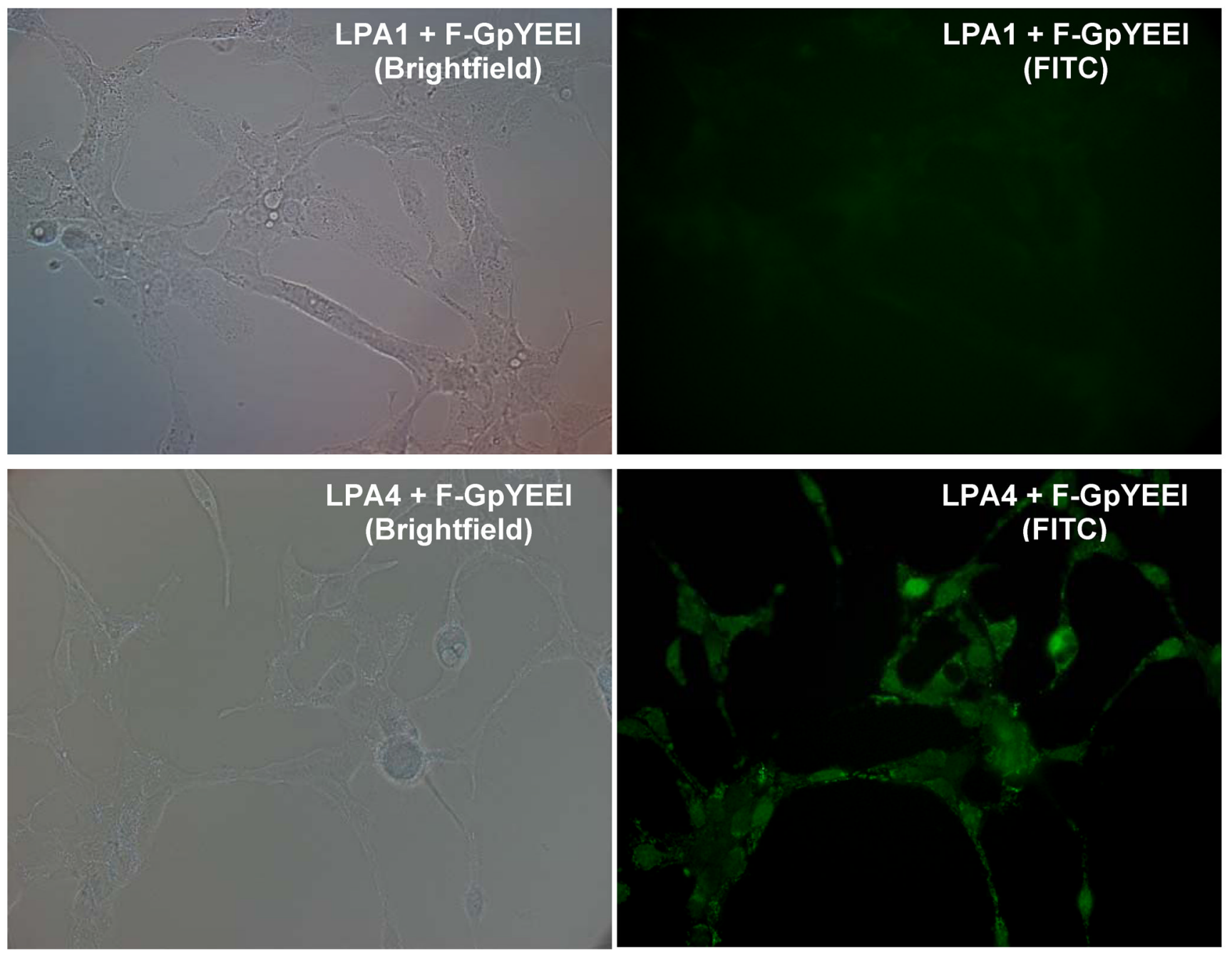

Figure 7.

Real time fluorescence microscopy of F-GpYEEI $(10 \mu \mathrm{M})$ in the presence of LPA4 $(50 \mu \mathrm{M})$ or LPA1 $(50 \mu \mathrm{M})$ using live BT-20 cells. 


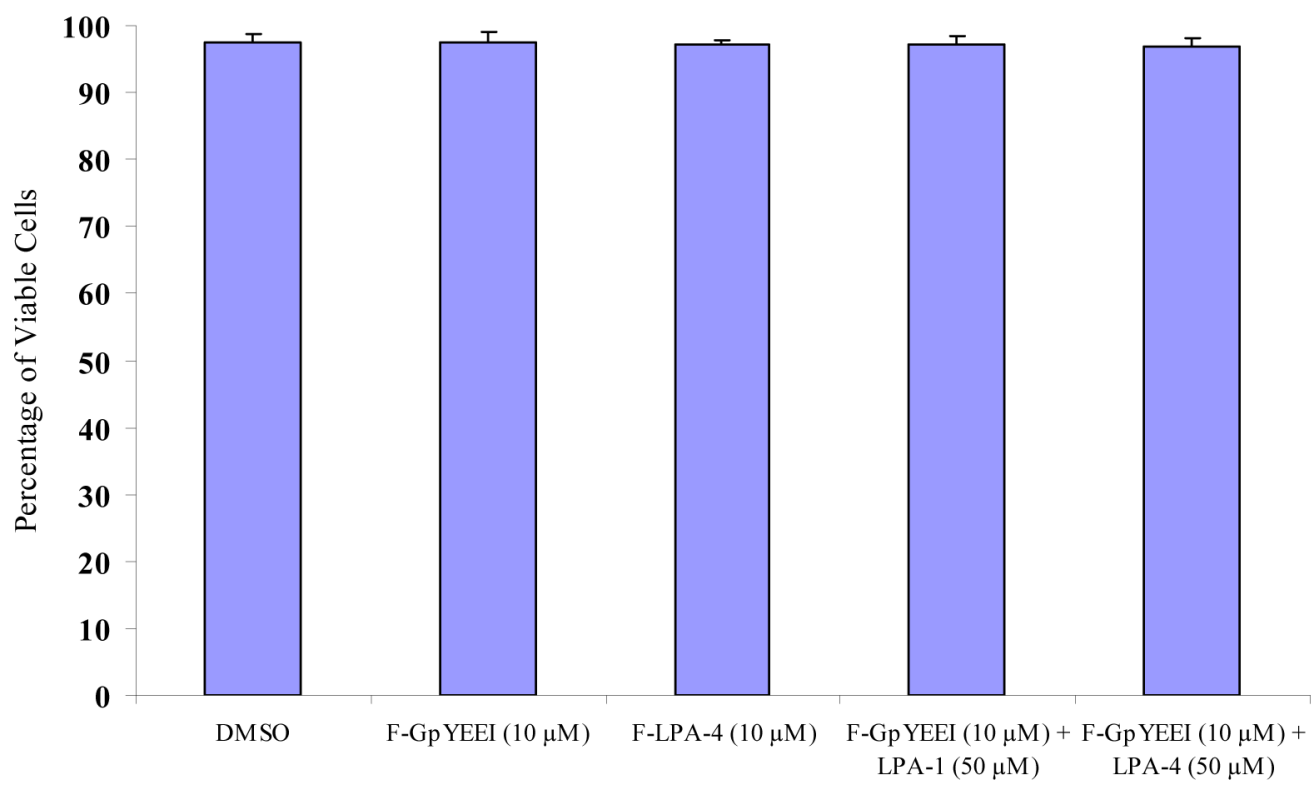

Figure 8.

Cell viability assay of F-GpYEEI, F-LPA4, F-GpYEEI + LPA1 and F-GpYEEI + LPA4. 


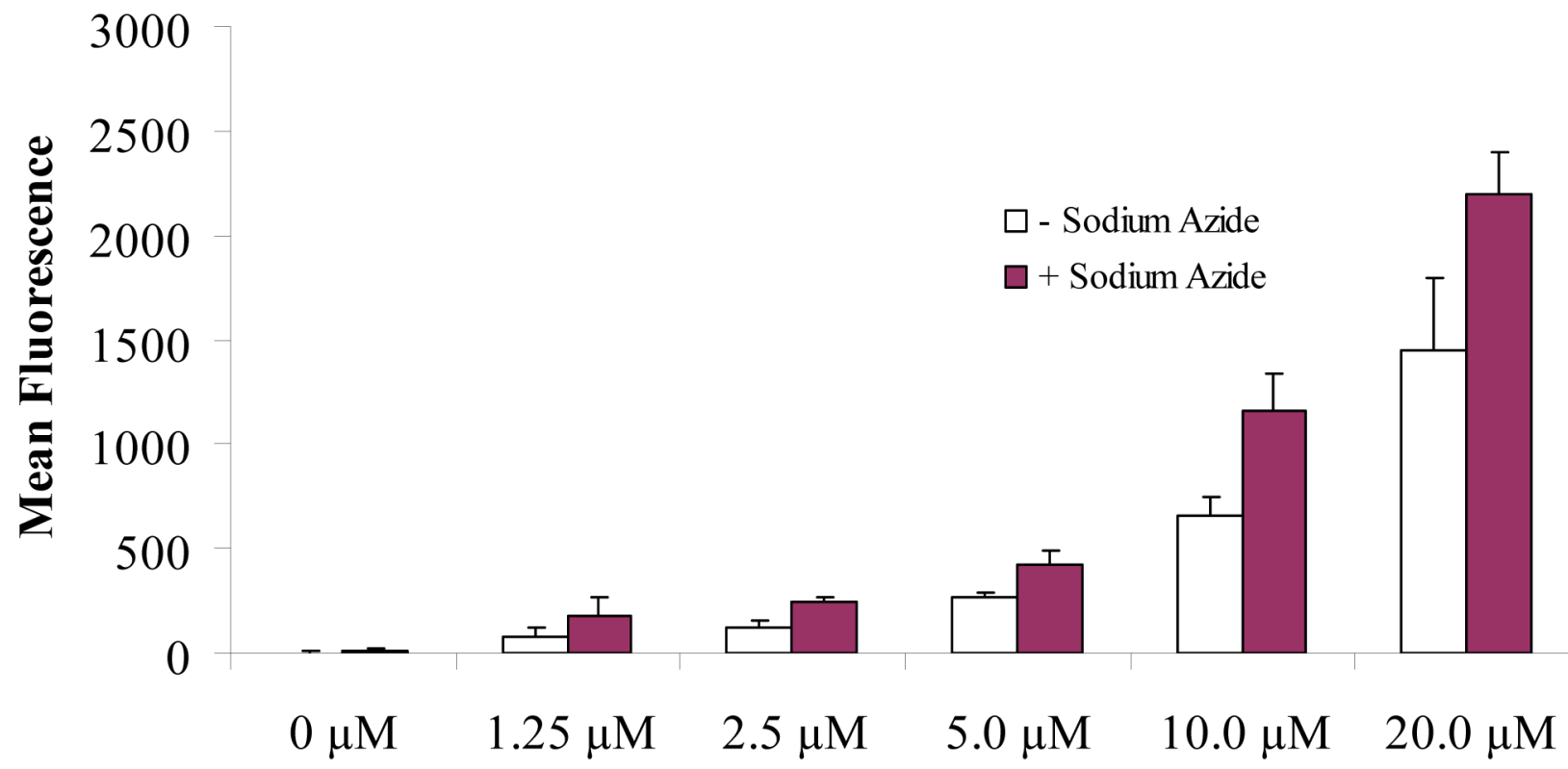

Figure 9.

Concentration-dependent cellular uptake of F-LPA4 in the presence and absence of sodium azide. 


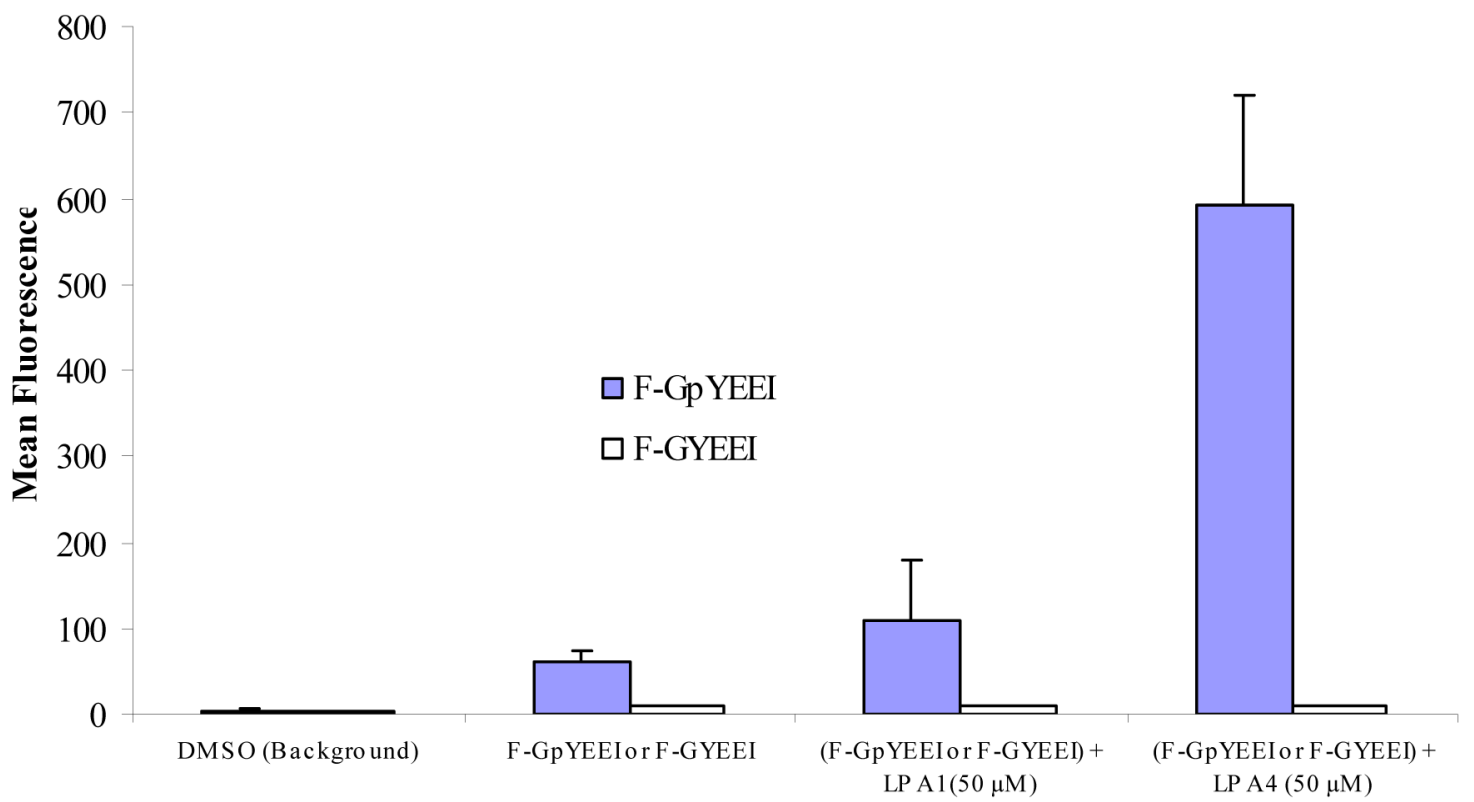

Figure 10.

FACS cellular uptake assay with F-GpYEEI vs. F-GYEEI $(10 \mu \mathrm{M})$ in the presence and absence of LPA-1 and LPA-4 $(50 \mu \mathrm{M})$. 

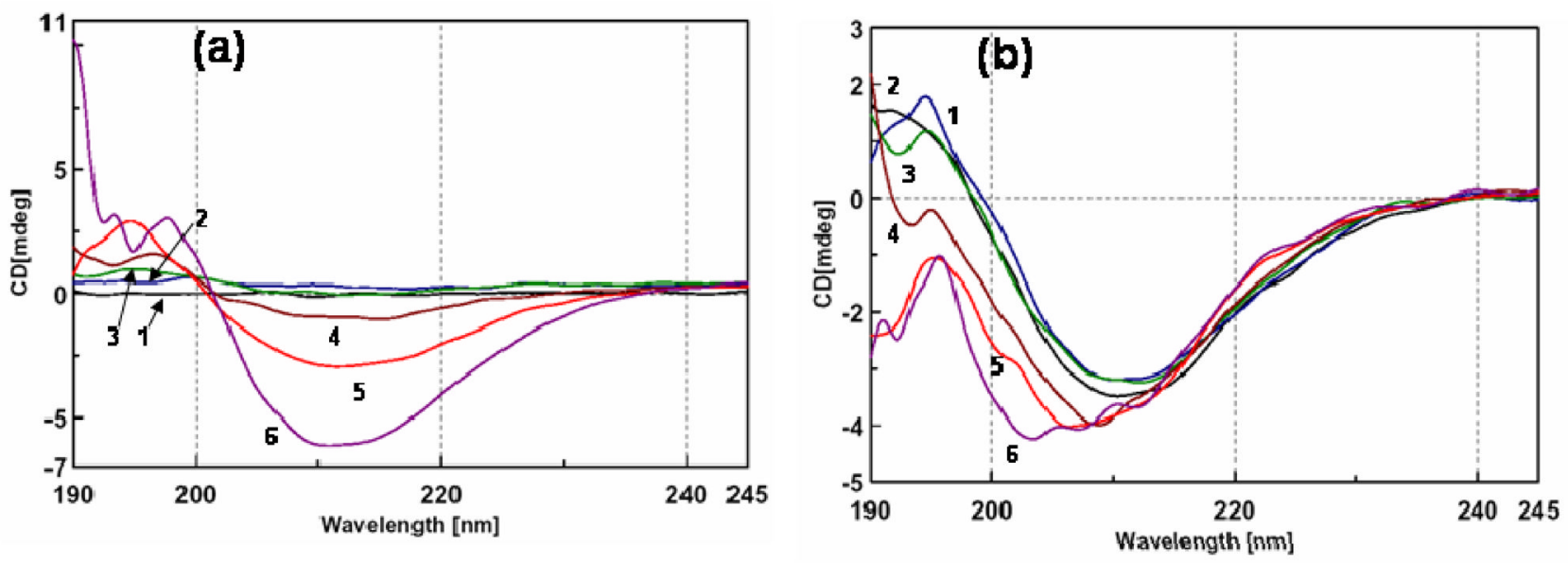

Figure 11.

(a) CD spectropolarimetry of LPA4 in different concentrations: $\mathbf{1}(1 \mu \mathrm{M}), \mathbf{2}(5 \mu \mathrm{M}), \mathbf{3}(10 \mu \mathrm{M})$, $4(25 \mu \mathrm{M}), \mathbf{5}(50 \mu \mathrm{M}), \mathbf{6}(100 \mu \mathrm{M})$; (b) CD spectropolarimetry of LPA4 $(50 \mu \mathrm{M})$ in the presence of different concentrations of F-GpYEEI: $1(0 \mu \mathrm{M}), \mathbf{2}(1 \mu \mathrm{M}), \mathbf{3}(5 \mu \mathrm{M}), \mathbf{4}(10 \mu \mathrm{M}), \mathbf{5}(15 \mu \mathrm{M})$, $6(20 \mu \mathrm{M})$. 


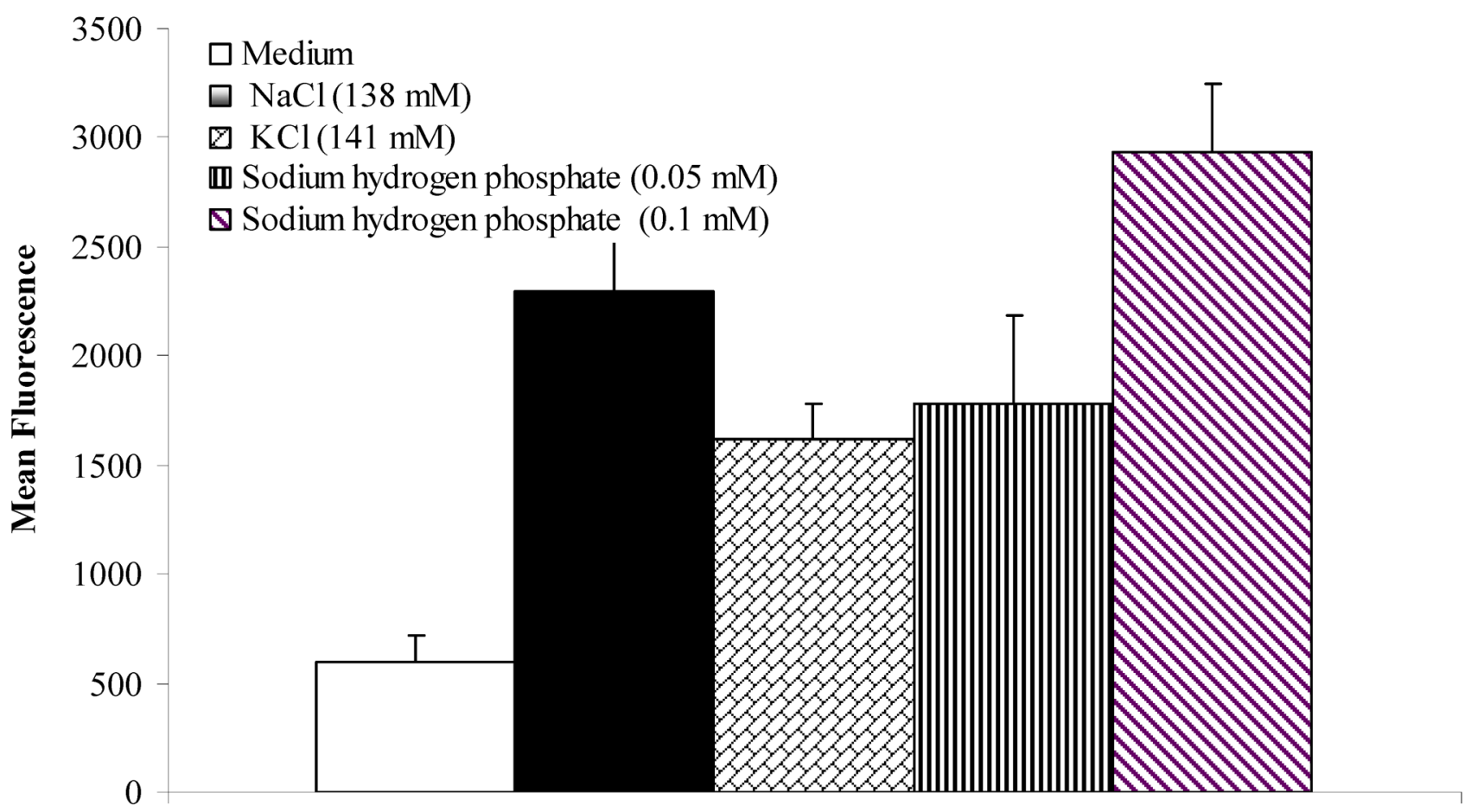

Figure 12.

Cellular uptake assay with F-GpYEEI $(10 \mu \mathrm{M})$ in the presence of LPA4 $(50 \mu \mathrm{M})$ in cell culture medium vs. $\mathrm{NaCl}, \mathrm{KCl}$, and sodium hydrogen phosphate solutions. 


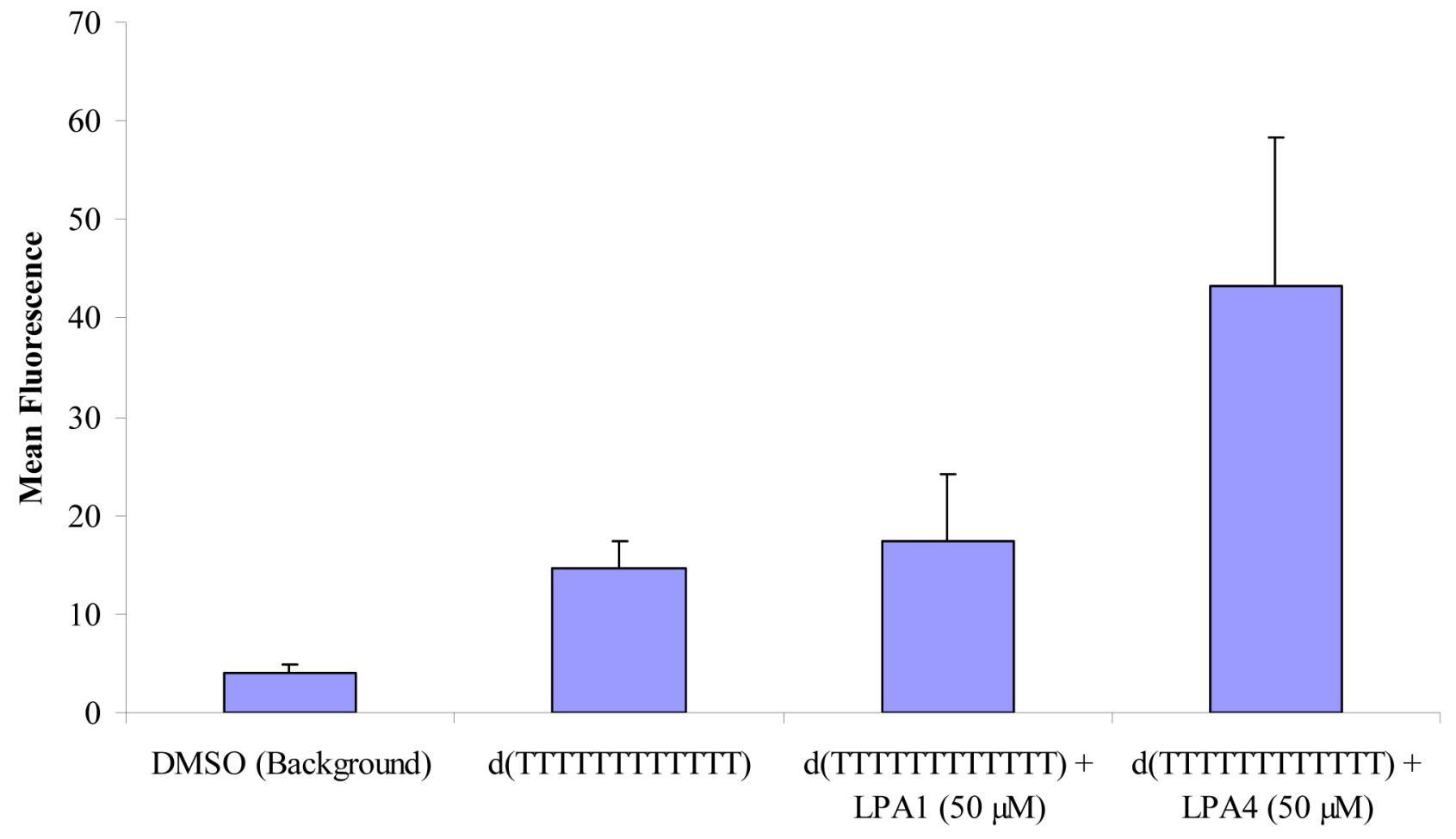

Figure 13.

Cellular uptake of 5'-fluorescence labeled d(TTTTTTTTTTTT) $(10 \mu \mathrm{M})$ in the presence of LPA-1 and LPA-4 (50 $\mu \mathrm{M})$. 


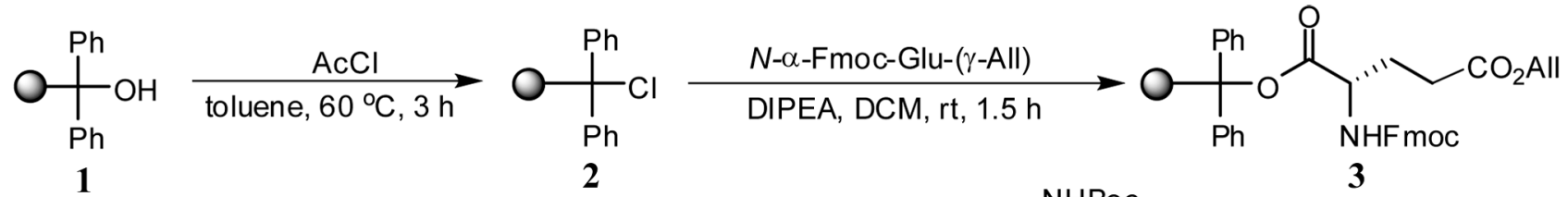

Fmoc-peptide synthesis protocol

(i) Fmoc-Arg(Pbf)-OH, HBTU, NMM

(ii) Piperidine/DMF (20\%)

(iii) Fmoc- $\beta-A l a-O H$, HBTU, NMM

(iv) Piperidine/DMF (20\%)

(v) Fmoc-Arg(Pbf)-OH, HBTU, NMM

(vi) Piperidine/DMF (20\%)

(vii) Fmoc- $\beta$-Ala-OH, HBTU, NMM

(viii) Piperidine/DMF (20\%)

(ix) Fmoc-Lys(Boc)-OH, HBTU, NMM

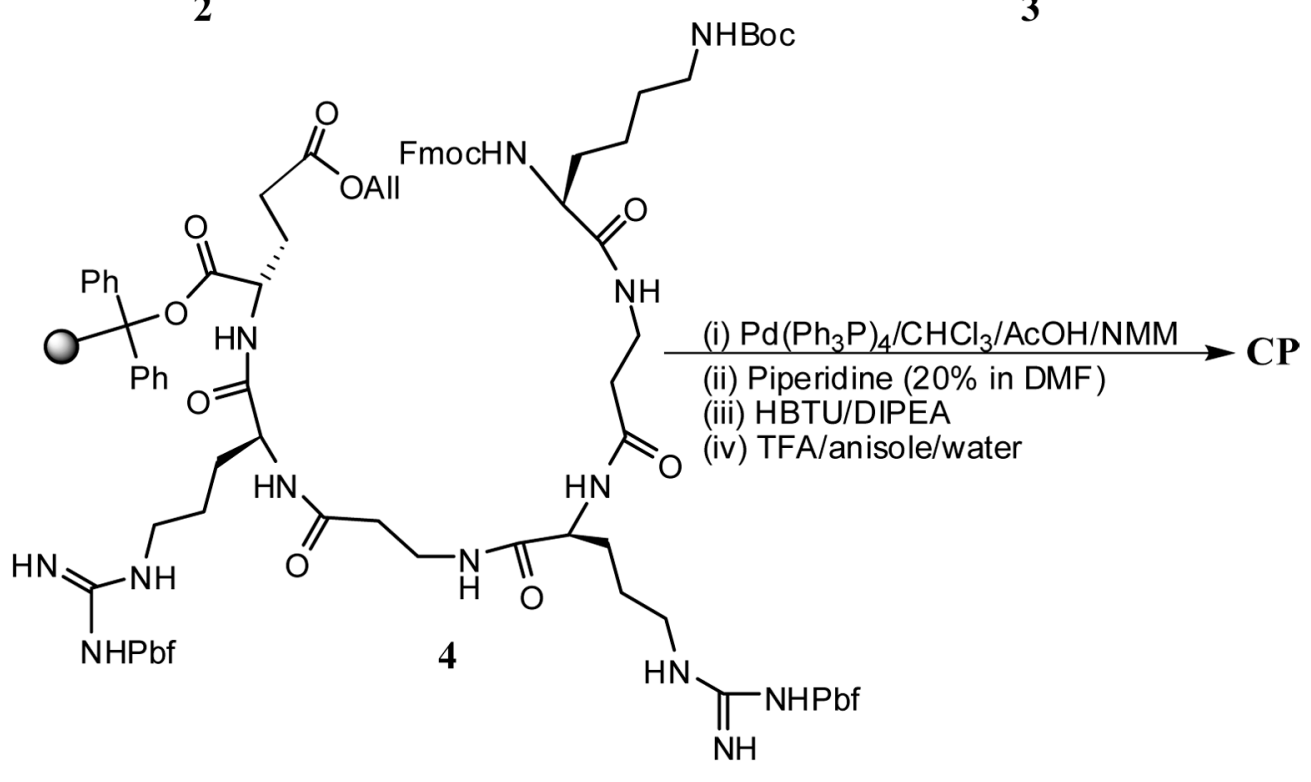

Scheme 1.

Synthesis of CP. 

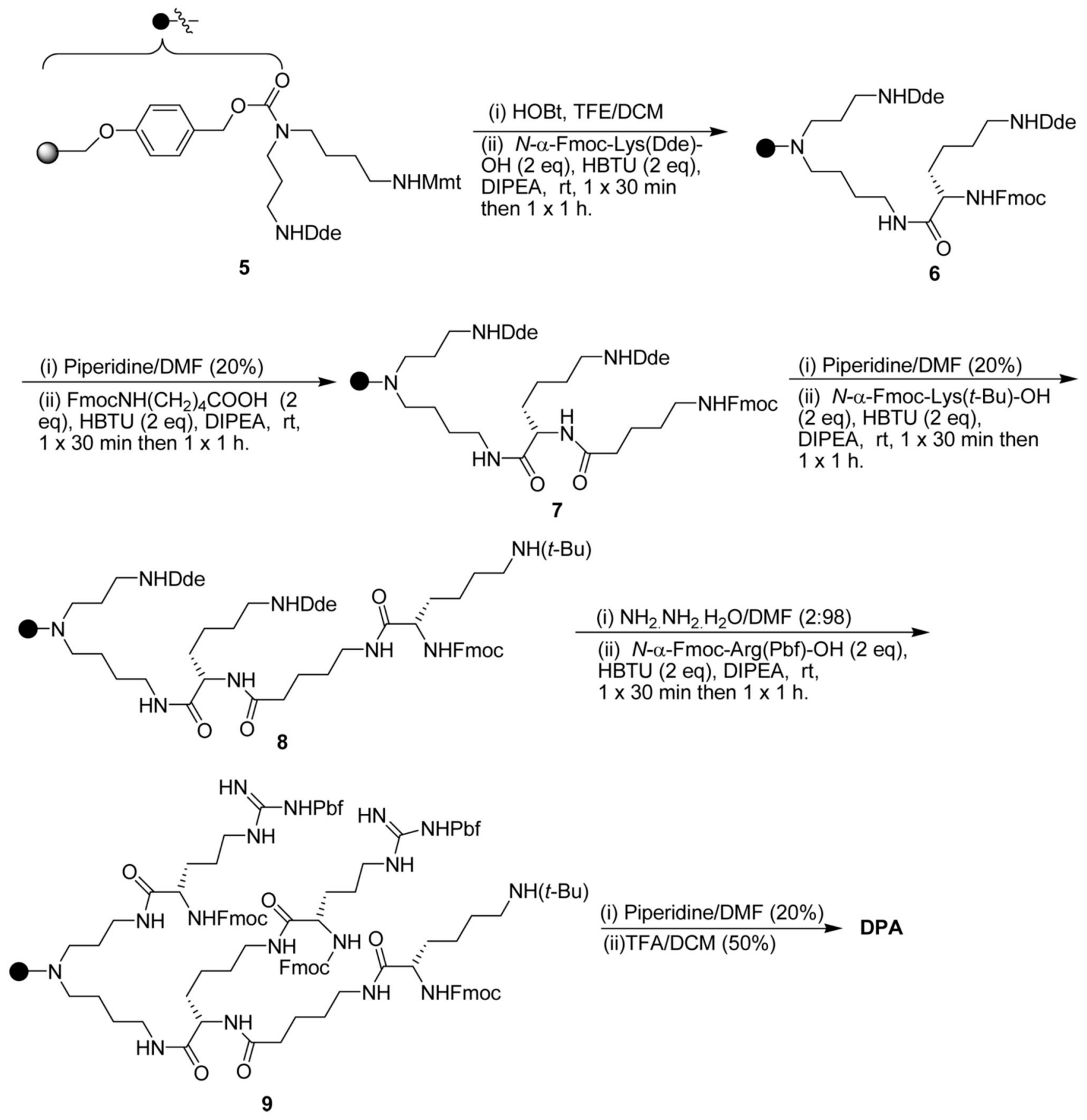

Scheme 2.

Synthesis of DPA. 


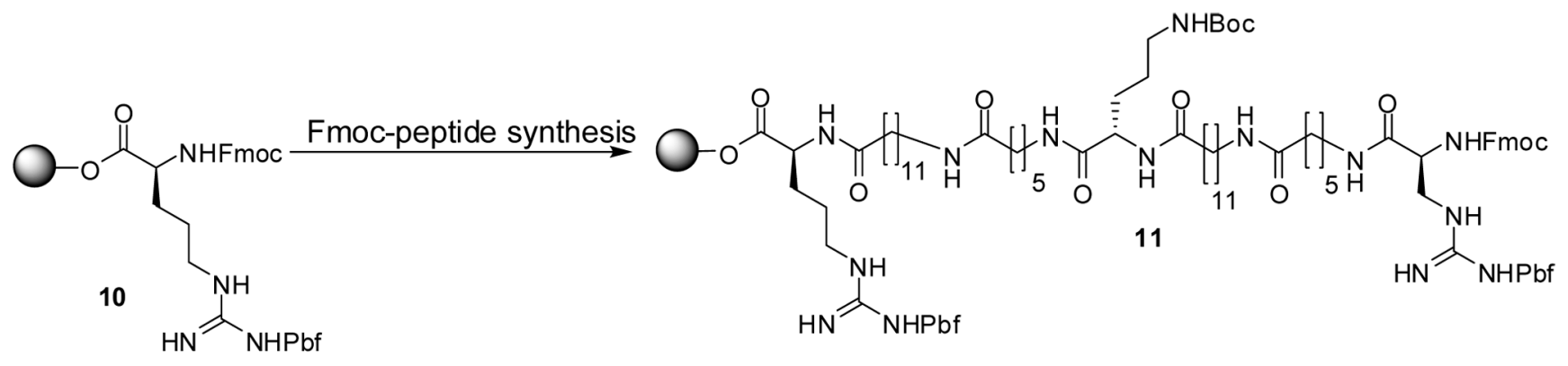

Scheme 3.

Fmoc peptide synthesis of LPA8. 


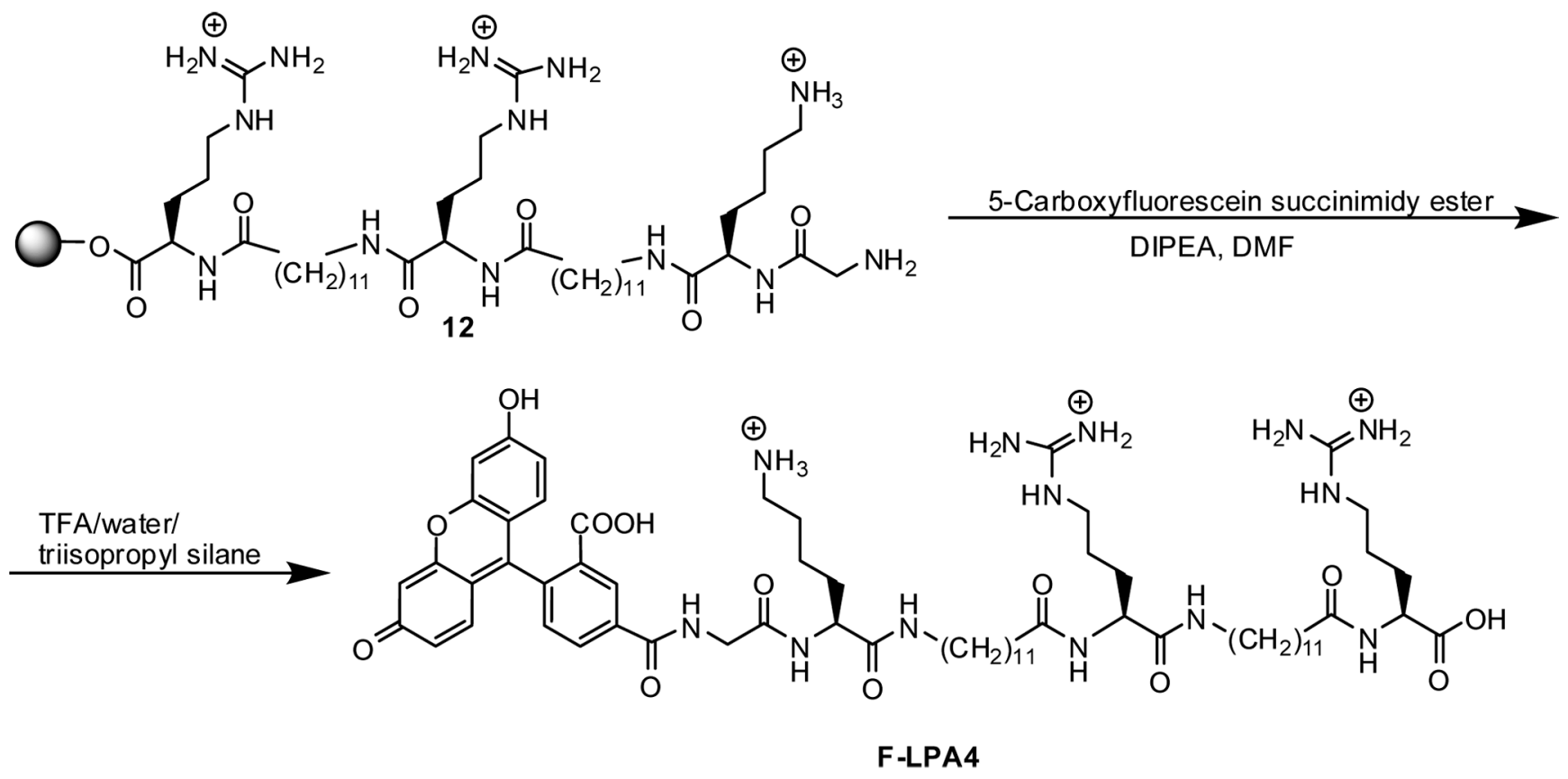

Scheme 4.

Synthesis of F-LPA4. 